\title{
Transient Receptor Potential Channels and Calcium Signaling
}

\author{
Laura Vangeel and Thomas Voets
}

Laboratory of Ion Channel Research, VIB Center for Brain and Disease Research \& Department of Cellular and Molecular Medicine, University of Leuven, B-3000 Leuven, Belgium

Correspondence: laura.vangeel@kuleuven.vib.be; thomas.voets@kuleuven.vib.be

Transient receptor potential (TRP) cation channels play diverse roles in cellular $\mathrm{Ca}^{2+}$ signaling. First, as $\mathrm{Ca}^{2+}$-permeable channels that respond to a variety of stimuli, TRP channels can directly initiate cellular $\mathrm{Ca}^{2+}$ signals. Second, as nonselective cation channels, TRP channel activation leads to membrane depolarization, influencing $\mathrm{Ca}^{2+}$ influx via voltage-gated and store-operated $\mathrm{Ca}^{2+}$ channels. Finally, $\mathrm{Ca}^{2+}$ modulates the activity of most TRP channels, allowing them to function as molecular effectors downstream of intracellular $\mathrm{Ca}^{2+}$ signals. Whereas the TRP channel field has long been devoid of detailed channel structures, recent advances, particularly in cryo-electron microscopy-based structural approaches, have yielded a flurry of TRP channel structures, including members from all seven subfamilies. These structures, in conjunction with mutagenesis-based functional approaches, provided important new insights into the mechanisms whereby TRP channels permeate and sense $\mathrm{Ca}^{2+}$. These insights will be highly instrumental in the rational design of novel treatments for the multitude of TRP channel-related diseases.

T ansient receptor potential (TRP) channels form a large branch within the superfamily of voltage-gated cation channels, which further contains the $\mathrm{K}^{+}$-selective channels, voltage-gated $\mathrm{Na}^{+}$channels, voltage-gated $\mathrm{Ca}^{2+}$ channels, cyclic nucleotide-gated channels, and two pore channels (TPCs) (Yu and Catterall 2004). The human genome encodes 27 TRP channel-encoding genes (Gees et al. 2012), and further TRP channel-encoding genes are found in all vertebrates, insects, worms, yeast, and even singlecelled algae (Harteneck et al. 2000; Arias-Darraz et al. 2015). The designation TRP originates from the trp gene in Drosophila, disruption of which leads to a transient receptor potential in the fly photoreceptors (Minke et al. 1975). As such, the name TRP is a relic from the past rather than an accurate description of the physiological properties of this family of channels, which are involved in diverse biological and pathophysiological processes, mostly completely unrelated to the transient nature of receptor potentials (Clapham 2003; Nilius et al. 2007; Venkatachalam and Montell 2007; Gees et al. 2012).

However, finding a more apt name for this group of channels is not evident: the TRP channel family is really a mixed bag, consisting of cation channels exhibiting a wide range of ion selectivities, gating mechanisms, and biological functions. Arguably, the most common feature

Editors: Geert Bultynck, Martin D. Bootman, Michael J. Berridge, and Grace E. Stutzmann

Additional Perspectives on Calcium Signaling available at www.cshperspectives.org

Copyright (C) 2019 Cold Spring Harbor Laboratory Press; all rights reserved; doi: 10.1101/cshperspect.a035048

Cite this article as Cold Spring Harb Perspect Biol 2019;11:a035048 
of TRP channels is that they make a substantial impact on cellular $\mathrm{Ca}^{2+}$ signaling. In particular, TRP channels can act as a pathway for $\mathrm{Ca}^{2+}$ to enter the cytosol, modulate the activity of other $\mathrm{Ca}^{2+}$-permeable channels, and translate changes in cytosolic $\mathrm{Ca}^{2+}$ into cation flux and electrical activity.

In this review, we summarize and discuss recent insights into the role of TRP channels in cellular $\mathrm{Ca}^{2+}$ signaling, with particular focus on the structural determinants of TRP channel$\mathrm{Ca}^{2+}$ interactions.

\section{$\mathrm{Ca}^{2+} \mathrm{ACTION}$ AND REACTION}

$\mathrm{Ca}^{2+}$ is a ubiquitous intracellular messenger, and $\mathrm{Ca}^{2+}$ signaling lies at the basis of innumerous biological processes, including cell adaptation, survival, and cell death (Berridge 2017). Adequate spatiotemporal regulation of intracellular $\mathrm{Ca}^{2+}$ therefore represents a central theme in every cell. TRP channels are tightly involved both in shaping $\mathrm{Ca}^{2+}$ signals and in responding to physiological changes in intracellular $\mathrm{Ca}^{2+}$ in animal cells.

TRP Channel Gating Shaping Cytosolic $\mathrm{Ca}^{2+}$ Signals

Based upon their relative permeability to $\mathrm{Ca}^{2+}$ and $\mathrm{Na}^{+}\left(\mathrm{P}_{\mathrm{Ca}} / \mathrm{P}_{\mathrm{Na}}\right)$, TRP channels can roughly be divided into three groups (Fig. 1; Owsianik et al. 2006). The majority of TRP channels are $\mathrm{Ca}^{2+}$-permeable nonselective cation channels with $\mathrm{P}_{\mathrm{Ca}} / \mathrm{P}_{\mathrm{Na}}$ values in the range between 0.1 and 20. In most cell types, opening of these TRP channels will induce an inward current that is carried by a mixture of $\mathrm{Na}^{+}$and $\mathrm{Ca}^{2+}$ ions (Mulier et al. 2017). The two closely homologous epithelial TRP channels TRPV5 and TRPV6 are exquisitely $\mathrm{Ca}^{2+}$-selective, with estimated $\mathrm{P}_{\mathrm{Ca}} / \mathrm{P}_{\mathrm{Na}}$ values exceeding 100 (Vennekens et al. 2000; Yue et al. 2001). Under physiological ionic conditions, these channels will generate inward currents that are almost exclusively carried by $\mathrm{Ca}^{2+}$ ions, similar to the high $\mathrm{Ca}^{2+}$ selectivity of voltage-gated $\mathrm{Ca}^{2+}$ channels and store-operated Orail channels. TRPM4 and TRPM5 are situated on the other end of the
$\mathrm{Ca}^{2+}$-selective

Nonselective
$\mathrm{Ca}^{2+}$-impermeable

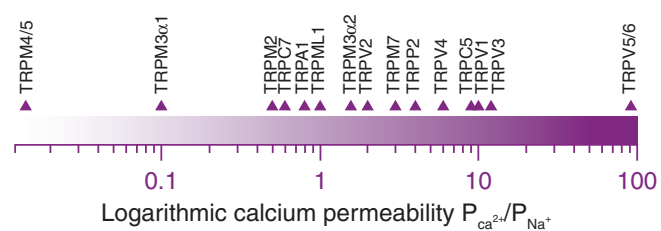

Figure 1. $\mathrm{Ca}^{2+}$ permeability of transient receptor potential (TRP) channels. On a logarithmic scale, these are examples of the indicated mammalian TRP channels illustrating the range of relative $\mathrm{Ca}^{2+}$ permeabilities (based on reversal potential measurements). Note that values are indicative, as the obtained values can vary significantly depending on cellular environment and experimental conditions.

selectivity spectrum, showing negligible permeability to $\mathrm{Ca}^{2+}$ ions $\left(\mathrm{P}_{\mathrm{Ca}} / \mathrm{P}_{\mathrm{Na}}<0.01\right)$. Inward currents mediated by these channels are mainly carried by $\mathrm{Na}^{+}$ions (Launay et al. 2002; Prawitt et al. 2003; Nilius et al. 2005).

Notwithstanding this diversity in the ion selectivity of their pores, it has already been wellestablished in the prestructural era that TRP channels share a common overall architecture, analogous to that of voltage-gated channels that mediate $\mathrm{K}^{+}, \mathrm{Na}^{+}$, or $\mathrm{Ca}^{2+}$ flux (Gaudet 2008). All TRP channel family members are proteins containing six transmembrane (TM) domains (S1 to S6) and relatively long intracellular amino and carboxyl termini. After assembly of four such TRP subunits into one functional tetramer, the domains S5 to S6 and the interconnecting loop complement into one central pore (Hoenderop et al. 2003; Gaudet 2008; Gees et al. 2012). In the last two decades, studies using a combination of site-directed mutagenesis, electrophysiology, and structural modeling have clearly established that amino acids lining this central pore tune the $\mathrm{Ca}^{2+}$ selectivity of TRP channel pores, and that variability in this region can explain to a large extent the differences in $\mathrm{Ca}^{2+}$ permeability between TRP channels. For instance, mutation of a single aspartate in the pore loop of TRPV5 and TRPV6 to a noncharged residue changes the selectivity of these 
channels from $\mathrm{Ca}^{2+}$-selective to nonselective (Nilius et al. 2001). Oppositely, mutation of a glutamine to a glutamate in the pore loop confers detectable $\mathrm{Ca}^{2+}$ permeability to TRPM4 (Nilius et al. 2005). Overall, the presence of negatively charged aspartate and glutamate residues in the pore loop was found to be a key determinant of $\mathrm{Ca}^{2+}$ permeability and selectivity (García-Martinez et al. 2000; Nilius et al. 2001, 2005; Hoenderop et al. 2003; Voets et al. 2003, 2004; Owsianik et al. 2006).

To determine the contribution of a TRP channel to cellular $\mathrm{Ca}^{2+}$ signaling, not only the pore properties but also the gating mechanisms need to be taken into account. TRP channel gating can be induced by a wide variety of physical and chemical stimuli (Table 1), and the relative permeability to $\mathrm{Ca}^{2+}$ ions will crucially determine the cell-physiological response to channel opening. Opening of $\mathrm{Ca}^{2+}$-permeable nonselective TRP channels evokes a cytosolic $\mathrm{Ca}^{2+}$ rise as well as membrane depolarization, both of which can trigger cellular responses. For instance, several TRP channels are expressed in sensory endings of somatosensory neurons, where they respond to innocuous and noxious stimuli. There, opening of $\mathrm{Ca}^{2+}$-permeable nonselective channels such as TRPA1, TRPV1, and TRPM3 not only causes depolarization that evokes action potential firing and propagation to the central nervous system to signal pain (Vandewauw et al. 2018), but also a local cytosolic $\mathrm{Ca}^{2+}$ rise that triggers neuropeptide release and neurogenic inflammation (Julius 2013). In the case of the $\mathrm{Ca}^{2+}$-selective TRPV5 and TRPV6, the entry of $\mathrm{Ca}^{2+}$ ions lies at the basis of their role in the selective epithelial uptake, and transepithelial transport, of $\mathrm{Ca}^{2+}$ (Hoenderop et al. 2005). Depending on the cellular context, opening of the $\mathrm{Ca}^{2+}$-impermeable TRPM4 and TRPM5 and the ensuing cell depolarization can either evoke, enhance, or dampen cytosolic $\mathrm{Ca}^{2+}$ signals. On the one hand, depolarization promotes gating of voltage-gated $\mathrm{Ca}^{2+}$ channels present in most excitable cells. On the other hand, TRPM4- and TRPM5-mediated depolarization reduces the driving force for $\mathrm{Ca}^{2+}$ influx through both voltage-gated and voltage-independent (e.g., storeoperated) $\mathrm{Ca}^{2+}$ channels, and can thus act as a break on $\mathrm{Ca}^{2+}$ entry (Liman 2007; Vennekens et al. 2007; Mathar et al. 2014).

To add to the complexity, a subset of TRP channels is functionally expressed at the membranes of intracellular organelles, including lysosomes and the endoplasmic reticulum (ER). Prominent example are the mucolipins (TRPML1, TRPML2, and TRPML3), which are predominantly found in organellar membranes. Mutations in TRPML1 cause the human lysosomal storage disease mucolipidosis type IV, and evidence is accumulating pointing at a crucial role for this channel in the transport of $\mathrm{Ca}^{2+}$ and other divalent cations across the lysosomal membrane as well as in lysosomal biogenesis and autophagy (Dong et al. 2008, 2010; Medina et al. 2015; Zhang et al. 2016). In addition, several TRP channels can be considered as noncommitted TRP channels, as they can function in the plasma membrane as well as in intracellular membranes (Zhang et al. 2018a). A prominent example is TRPM2, which is best known as a plasma membrane channel activated by intracellular $\mathrm{Ca}^{2+}$ and intracellular ligands such ADP-ribose (ADPR), and by the recently discovered superagonist 2'-deoxy ADPR (Perraud et al. 2001; Sano et al. 2001; Fliegert et al. 2017), but can also act as a lysosomal $\mathrm{Ca}^{2+}$-release channel (Lange et al. 2009). A more elaborate review on intracellular TRP channels can be found elsewhere (Zhang et al. 2018a).

\section{Cytosolic $\mathrm{Ca}^{2+}$ Signals Shaping TRP Channel Activity}

Besides TRP channel gating shaping cellular $\mathrm{Ca}^{2+}$ signals, cytosolic $\mathrm{Ca}^{2+}$ itself also modulates the activity of several TRP channels. The action of $\mathrm{Ca}^{2+}$ on TRP channel gating can be both stimulatory and inhibitory, and can either be mediated via direct channel- $\mathrm{Ca}^{2+}$ interaction or alternatively involve cytosolic $\mathrm{Ca}^{2+}$-binding proteins and/or $\mathrm{Ca}^{2+}$-dependent signal transduction pathways (Fig. 2).

There are only a few examples in the literature of $\mathrm{Ca}^{2+}$-binding sites in the cytosolic domains of TRP channels that have been proposed to contribute to direct effects of cytosolic $\mathrm{Ca}^{2+}$ on channel gating. These include an EF-hand 
L. Vangeel and T. Voets

Table 1. Activation and regulation mechanisms of TRP channels

\begin{tabular}{|c|c|c|c|c|}
\hline & Representative ligand & {$[\text { Calcium }]_{\mathrm{i}}$} & $\mathrm{T}^{\circ}$ & $\begin{array}{c}\text { Voltage } \\
\text { dependence }\end{array}$ \\
\hline TRPA1 & AITC & $\begin{array}{l}\text { +: Direct }\left(\text { low } \mathrm{Ca}^{2+}\right) \\
\text {-: Direct/CaM }\left(\text { high } \mathrm{Ca}^{2+}\right)\end{array}$ & 料, 凹 & 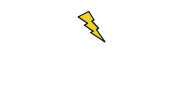 \\
\hline TRPC1 & & & & \\
\hline TRPC2 & DAG & $-:$ & & \\
\hline TRPC3 & DAG & -: CaM & & \\
\hline TRPC4 & $\mathrm{Gd}^{3+}$ & -: CaM & & \\
\hline TRPC5 & $\mathrm{Gd}^{3+}$ & $+: \mathrm{Ca}^{2+}$ & 橉 & \& \\
\hline TRPC6 & DAG & & & \\
\hline TRPC7 & DAG & -: CaM & & \\
\hline TRPM1 & PS & & & \\
\hline TRPM2 & $2^{\prime}$-deoxy-ADPR & $+: \mathrm{CaM}$, direct & & \\
\hline TRPM3 & PS, CIM0216 & -: $\mathrm{PIP}_{2}$ depletion & 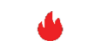 & 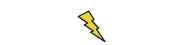 \\
\hline TRPM4 & Decavanadate & $\begin{array}{l}\text { +: Direct } \\
\text {-: } \text { PIP }_{2} \text { depletion }\end{array}$ & 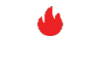 & $\hat{3}$ \\
\hline TRPM5 & $\mathrm{Ca}^{2+}$ & $\begin{array}{l}\text { +: Direct } \\
\text {-: } \mathrm{PIP}_{2} \text { depletion }\end{array}$ & $\Delta$ & 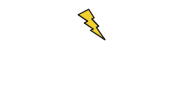 \\
\hline TRPM6 & & -: $\mathrm{PIP}_{2}$ depletion & & \\
\hline TRPM7 & Naltriben & -: $\mathrm{PIP}_{2}$ depletion & & \\
\hline TRPM8 & Menthol & -: $\mathrm{PIP}_{2}$ depletion & 整 & 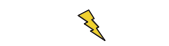 \\
\hline TRPML1 & $\mathrm{PI}(3,5) \mathrm{P}_{2}$ & -: Direct $\mathrm{Ca}^{2+}$ block & & \\
\hline TRPML2 & SF-11, SN-1 & & & \\
\hline TRPML3 & SF-21/41/81 & & & \\
\hline $\begin{array}{l}\text { TRPP1-PKD2 } \\
\text { TRPP2-PKD2 L1 } \\
\text { TRPP3-PKD2 L2 }\end{array}$ & & +: Direct & & $\xi$ \\
\hline TRPV1 & Capsaicin & -: CaM, $\mathrm{PIP}_{2}$ depletion & 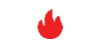 & $\xi$ \\
\hline TRPV2 & THC & -: $\mathrm{PIP}_{2}$ depletion & 4 & \\
\hline TRPV3 & 2-APB & $+: \mathrm{CaM}+$ direct & $\Delta$ & $\xi$ \\
\hline TRPV4 & GSK-1016790A & $\begin{array}{l}\text { +: CaM } \\
\text {-: Desensitization (?) }\end{array}$ & $\Delta$ & \\
\hline TRPV5 & & -: CaM, Calbindin-D28K, $\mathrm{PIP}_{2}$ depletion & & \\
\hline TRPV6 & & -: CaM, $\mathrm{PIP}_{2}$ depletion & & \\
\hline
\end{tabular}

䊏, cold temperatures; $\boldsymbol{\omega}$, warm temperatures; $\}$, voltage-gated.

2-APB, 2-aminoethoxydiphenyl borate; AICT, allyl isothiocyanate; CaM, calmodulin; DAG, diacylglycerol; $\mathrm{PIP}_{2}$, phosphatidylinositol bisphosphate; PS, pregnenolone sulfate; SF, SN, sulfonamides; THC, tetrahydrocannabinol.

structure in both the amino-terminal domain of TRPA1 and in the cytosolic side of the S1-S4 region in TRPM4 that have been implicated in $\mathrm{Ca}^{2+}$-induced channel activation (Doerner et al. 2007; Zurborg et al. 2007; Autzen et al. 2018).

A more common means whereby $\mathrm{Ca}^{2+}$ can affect TRP channel activity involves cytosolic $\mathrm{Ca}^{2+}$-binding proteins, with calmodulin $(\mathrm{CaM})$ being the most prominent one. CaM-binding domains (CaMBDs) have been identified in the cytosolic regions of different TRP channels, includ- ing sites where $\mathrm{CaM}$ binds in the apo $\left(\mathrm{Ca}^{2+}\right.$-free $)$ and $\mathrm{Ca}^{2+}$-bound $\left(\mathrm{Ca}^{2+}-\mathrm{CaM}\right)$ conformations. The effect of $\mathrm{Ca}^{2+}$-CaM on TRP channel gating is channel-dependent. For example, binding of $\mathrm{Ca}^{2+}$-CaM to one of the CaMBDs located in the cytosolic amino- or carboxyl termini, underlies $\mathrm{Ca}^{2+}$-dependent inactivation of TRP channels. This is exemplified by the highly $\mathrm{Ca}^{2+}$-selective epithelial channels TRPV5 and TRPV6, where $\mathrm{CaM}$-dependent inactivation functions as a fast feedback mechanism to maintain a tight $\mathrm{Ca}^{2+}$ 


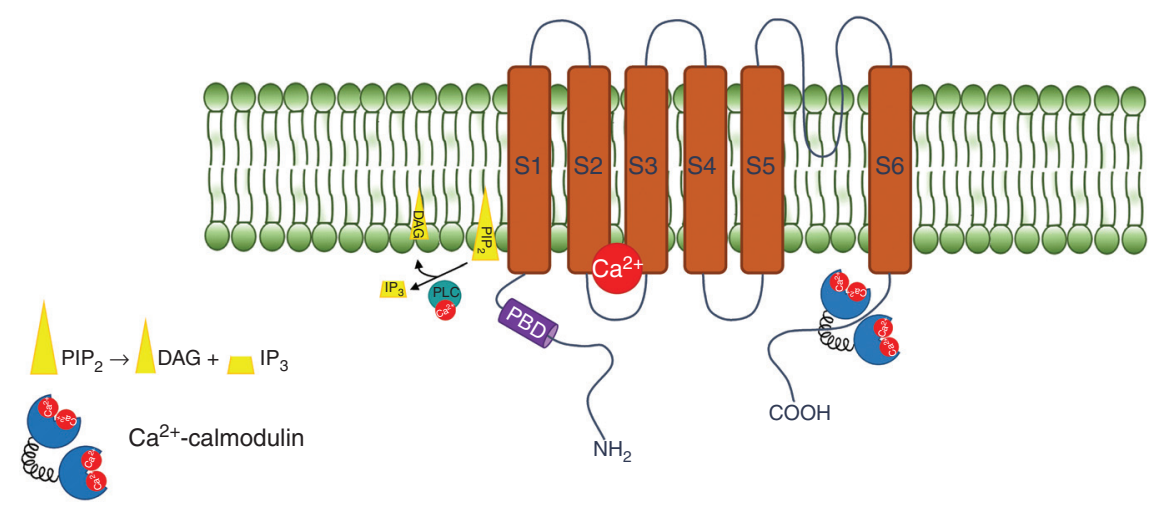

Figure 2. Cartoon illustrating three general mechanisms of $\mathrm{Ca}^{2+}$-dependent regulation of transient receptor potential (TRP) channel activity. (Left) $\mathrm{Ca}^{2+}$ (red spheres) can cause a decrease in the plasma membrane PIP 2 levels via $\mathrm{Ca}^{2+}$-activated phospholipase $\mathrm{C}$. This decrease is sensed by $\mathrm{PIP}_{2}$-binding domains (PBDs, purple), which are found at various locations in the cytosolic part of TRP channels. (Center) $\mathrm{Ca}^{2+}$ can bind directly to activate TRP channels, for instance, via residues in the S2-S3 region of TRPM channels. (Right) $\mathrm{Ca}^{2+}$ can influence TRP channel activity via calmodulin (CaM, blue), for example, via $\mathrm{Ca}^{2+}-\mathrm{CaM}$ binding in the carboxyl terminus of TRPV channels.

homeostasis and prevent excessive $\mathrm{Ca}^{2+}$ influx (Kovalevskaya et al. 2012). In TRPV1, $\mathrm{Ca}^{2+}$-CaM exerts a dual effect on channel desensitization, involving both a direct interaction with cytosolic CaMBDs as well as an indirect modulation via $\mathrm{Ca}^{2+}$-CaM-dependent protein kinase II (CaMKII)-dependent channel phosphorylation (Bonnington and McNaughton 2003; Lau et al. 2012). In contrast, binding of $\mathrm{Ca}^{2+}-\mathrm{CaM}$ to TRPV3 was proposed to sensitize the channel to repeated stimuli, although the underlying mechanism is unclear (Xiao et al. 2008). In addition to $\mathrm{CaM}$, other $\mathrm{Ca}^{2+}$-binding proteins have also been shown to interact with, and regulate, TRP channels. Examples include $80 \mathrm{~K}-\mathrm{H}$ and Calbindin-D28K interacting with TRPV5 (Lambers et al. 2006), and S100A1 interacting with TRPA1 and TRPM3 (Holakovska et al. 2012).

A third and frequently observed mechanism whereby $\mathrm{Ca}^{2+}$ affects TRP channel function is through activation of phospholipase C (PLC), which catalyzes the hydrolysis of phosphatidylinositol 4,5-bisphophate $\left(\mathrm{PIP}_{2}\right)$ in the plasma membrane into the second messengers inositol 1,4,5-trisphosphate $\left(\mathrm{IP}_{3}\right)$ and diacylglycerol (DAG) (Rohacs 2014). Whereas some PLC isoforms are activated by G-protein coupled recep- tors (GPCRs), others (PLC $\delta 1, \delta 3$, and $\delta 4$ ) can be activated by a rise in cytosolic $\mathrm{Ca}^{2+}$, for instance upon TRP channel activation. For most TRP channels, $\mathrm{PIP}_{2}$ acts as a positive regulator of channel activity, and consequently $\mathrm{PIP}_{2}$ hydrolysis at the plasma membrane, whether through $\mathrm{Ca}^{2+}$ - or GPCR-dependent activation of PLC, causes channel desensitization; yet, there are also examples of inhibitory and bimodal effects of $\mathrm{PIP}_{2}$ on TRP channel gating (Chuang et al. 2001; Lukacs et al. 2007; Zhang et al. 2012; Rohacs 2014).

A more elaborate review on the effect of $\mathrm{Ca}^{2+}$ on TRP channels can be found elsewhere (Hasan and Zhang 2018).

\section{TRP CHANNELS ENTERING THE STRUCTURAL AREA}

Given the varied and intricate interplay between TRP channels and cellular $\mathrm{Ca}^{2+}$ signaling, important questions have been raised regarding the interaction of TRP channels with $\mathrm{Ca}^{2+}$ and $\mathrm{Ca}^{2+}$-regulated processes at the submolecular level. Such information is not only of fundamental interest, to elucidate the structural basis of the divergent permeability and gating properties of the different TRP channels, but also highly rele- 
vant to understanding the pathophysiological consequences of disease-causing mutations in TRP channels and to develop specific pharmacological approaches for the treatment of TRP channel-related human diseases (Nilius et al. 2007; Nilius and Voets 2013).

\section{The Resolution Revolution}

Although the first TRP gene was cloned in 1989 (Montell and Rubin 1989), it took almost 25 years until the first near-atomic-resolution TRP channel structure was resolved. Before that, high-resolution structural details were only available for a small number of specific intracellular domains of TRP channels (e.g., Yamaguchi et al. 2001), and insights into the 3D structure of entire TRP channels was limited to lower-resolution cryoelectron microscopy (cryo-EM) images, atomic force microscopy (e.g., Barrera et al. 2007; Gaudet 2008; Moiseenkova-Bell and Wensel 2009), and homology modeling using potassium channel structures as templates (e.g., Kalia and Swartz 2013). The lack of progress was partly a result of difficulties in purifying membrane proteins into a stable, native protein conformation after removal from membrane detergents (Whited and Park 2014), as well as to the large cytoplasmic domains of TRP channels displaying significant flexibility and thereby hindering crystallization. Fortunately, recent advantages in cryo-EM, driven by developments in detectors and single-particle analysis (Kühlbrandt 2014), have led to a revolution in TRP channel structural biology (Madej and Ziegler 2018). In 2013, the sidechain resolution barrier was broken for the first time for membrane proteins without crystallization, when structures of TRPV 1 were determined at a $3.4 \AA$ resolution (Liao et al. 2013). This was achieved by combining a new, direct electron detector with novel image processing algorithms, thereby greatly improving the signal and correcting for motion-induced blurring. This accomplishment is regarded as a major breakthrough in the world of structural biology and in the TRP channel field. These studies were the start of a resolution revolution, with an exponential increase in the number of structures of ion channels and other membrane proteins re- solved at atomic detail (Kühlbrandt 2014; Cheng 2015). As a result, detailed structures of at least one member of each TRP subfamily has been unraveled, providing insight into ion permeation and gating with resolution in the $3-4 \AA$ range (Table 2).

TRPV1 Structures: A Paradigm of TRP Channel Architecture and Gating

The cryo-EM structure of TRPV1 revealed an architecture characterized by a fourfold symmetry around a central ion permeation pore formed by TM domains S5 to S6 and the intervening pore loop (S5-P-S6), surrounded by four independently folded modules composed of domains S1 to S4 (Liao et al. 2013). Overall, this architecture is very similar to that of voltagegated $\mathrm{K}^{+}, \mathrm{Na}^{+}$, and $\mathrm{Ca}^{2+}$ channels (Kuang et al. 2015). The TRPV1 channel exhibits a wide extracellular mouth but a short selectivity filter, which sculpts the upper part of the gate (Liao et al. 2013). The conserved TRP domain that follows S6 interacts with the S4-S5 linker, which may facilitate coupling between different channel domains important for allosteric modulation. The assembly into tetramers is facilitated by interactions among cytoplasmic domains of the subunits. The ARD in the amino terminus is followed by a tightly packed linker that makes the connection with the pre-S1 helix.

These initial studies reported not only the structure of TRPV1 in its unliganded state (Liao et al. 2013), but also two structures obtained in the presence of ligand activators (Cao et al. 2013), allowing a first insight into possible structural rearrangements during channel gating. These ligand-bound TRPV1 structures included one obtained in the presence of the canonical vanilloid activator capsaicin, as well as one combining the ultrapotent vanilloid resiniferatoxin (RTX) with the double-knot toxin (DkTx), which in functional assays traps the channel in a fully open state. In these structures, the vanilloid-binding site was found buried in the channel complex in a binding pocket between the S4-S5 linker of one subunit and S6 of a neighboring subunit. In the RTX/DkTxbound structure, four toxin moieties were ob- 
TRP Channels and Calcium Signaling

Table 2. Overview of structures of integral transient receptor potential (TRP) channel proteins

\begin{tabular}{|c|c|c|c|c|c|c|}
\hline & Species & Method & Resolution & Condition and state & References & PDB \\
\hline TRPA1 & Human & Cryo-EM & $4 \AA$ & $\begin{array}{l}\text { Agonist AITC } \\
\text { Antagonist HC-030031 } \pm \\
\text { A-967079 }\end{array}$ & Paulsen et al. 2015 & $3 \mathrm{~J} 9 \mathrm{P}$ \\
\hline \multicolumn{7}{|l|}{ TRPC1 } \\
\hline \multirow[t]{3}{*}{ TRPC3 } & Human & $\begin{array}{l}\text { Cryo-EM (lipid } \\
\text { nanodisc) }\end{array}$ & $4.4 \AA$ & $\begin{array}{l}\text { Lipid-activator OAG pore } \\
\quad \text { (closed state) }\end{array}$ & Tang et al. 2018 & $5 Z B G$ \\
\hline & Human & Cryo-EM & $3.3 \AA$ & $\begin{array}{l}\text { Lipid-occupied } \\
\text { (closed state) }\end{array}$ & Fan et al. 2018 & 6CUD \\
\hline & Human & Cryo-EM & $5.8 \AA$ & In detergent (GDN) & $\begin{array}{l}\text { Sierra-Valdez } \\
\text { et al. } 2018\end{array}$ & 6DJS/R \\
\hline \multirow[t]{2}{*}{ TRPC4 } & Zebrafish & Cryo-EM & $3.6 \AA$ & Apo state (closed) & $\begin{array}{l}\text { Vinayagam et al. } \\
2018\end{array}$ & $6 \mathrm{G} 1 \mathrm{~K}$ \\
\hline & Mouse & Cryo-EM & $3.3 \AA$ & $\begin{array}{l}\text { Apo state (closed/ } \\
\text { inactivated state) }\end{array}$ & Duan et al. 2018a & $5 Z 96$ \\
\hline \multicolumn{7}{|l|}{ TRPC5 } \\
\hline TRPC6 & Human & $\begin{array}{l}\text { Cryo-EM (lipid } \\
\text { nanodisc) }\end{array}$ & $3.8 \AA$ & $\begin{array}{l}\text { Complex with inhibitor } \\
\text { BTDM (closed) }\end{array}$ & Tang et al. 2018 & $5 Y X 9$ \\
\hline \multicolumn{7}{|l|}{ TRPC7 } \\
\hline \multirow[t]{4}{*}{$\begin{array}{l}\text { TRPM1 } \\
\text { TRPM2 }\end{array}$} & $\begin{array}{c}\text { Nematostella } \\
\text { vectensis }\end{array}$ & Cryo-EM & $3 \AA$ & $\mathrm{Ca}^{2+}$-bound (closed state) & Zhang et al. $2018 \mathrm{~b}$ & $6 \mathrm{CO} 7$ \\
\hline & Zebrafish & Cryo-EM & $3.8 \AA$ & Apo state (closed) & Huang et al. 2018 & $\begin{array}{l}\text { 6DRK } \\
6 \mathrm{DRJ}\end{array}$ \\
\hline & & & $3.3 \AA$ & $\begin{array}{l}\mathrm{ADPR} / \mathrm{Ca}^{2+} \text {-bound state } \\
\quad \text { (active) }\end{array}$ & & \\
\hline & Human & Cryo-EM & $3.6 \AA$ & $\begin{array}{l}\text { Apo state } \\
\text { ADPR-bound } \\
\text { ADPR/Ca } / a^{2+} \text {-bound }\end{array}$ & Wang et al. 2018 & $\begin{array}{l}6 \mathrm{MIX} \\
6 \mathrm{MIZ} \\
6 \mathrm{MJ} 2\end{array}$ \\
\hline \multicolumn{7}{|l|}{ TRPM3 } \\
\hline \multirow[t]{5}{*}{ TRPM4 } & Human & $\begin{array}{l}\text { Cryo-EM (lipid } \\
\text { nanodisc) }\end{array}$ & $3 \AA$ & $\begin{array}{l}\mathrm{Ca}^{2+} \text {-free state } \\
\mathrm{Ca}^{2+} \text {-bound state }\end{array}$ & Autzen et al. 2018 & $\begin{array}{l}\text { 6BQR } \\
6 \mathrm{BQV}\end{array}$ \\
\hline & Human & Cryo-EM & $3.7 \AA$ & $\begin{array}{l}\text { Closed, } \mathrm{Na}^{+} \text {-bound (apo } \\
\text { state) }\end{array}$ & Duan et al. $2018 \mathrm{c}$ & 6BWI \\
\hline & Mouse & Cryo-EM & $3 \AA$ & Without ATP & Guo et al. 2017 & $\begin{array}{l}6 \mathrm{BCJ} \\
6 \mathrm{BCL}\end{array}$ \\
\hline & & & & ATP-bound & & $\begin{array}{l}6 \mathrm{BCO} \\
6 \mathrm{BCQ}\end{array}$ \\
\hline & Human & Cryo-EM & $3.8 \AA$ & $\begin{array}{l}\text { Bound to } \mathrm{Ca}^{2+} \text { (agonist) } \\
\text { and to decavanadate } \\
\text { (DVT) }\end{array}$ & $\begin{array}{l}\text { Winkler et al. } \\
2017\end{array}$ & 5WP6 \\
\hline \multicolumn{7}{|l|}{ TRPM5 } \\
\hline TRPM7 & Mouse & Cryo-EM & $\begin{array}{l}3.28 \AA \\
3.7 \AA \\
4.1 \AA\end{array}$ & $\begin{array}{l}\text { With EDTA } \\
\mathrm{Mg}^{2+} \text {-bound } \\
\mathrm{Mg}^{2+} \text {-unbound (divalent } \\
\text { free) }\end{array}$ & Duan et al. $2018 b$ & $\begin{array}{l}5 \mathrm{ZX5} \\
6 \mathrm{BWD} \\
6 \mathrm{BWF}\end{array}$ \\
\hline TRPM8 & $\begin{array}{l}\text { Ficedula } \\
\quad \text { albicollis }\end{array}$ & Cryo-EM & $4.1 \AA$ & Nonconducting state & Yin et al. 2018 & $6 \mathrm{BPQ}$ \\
\hline
\end{tabular}


L. Vangeel and T. Voets

Table 2. Continued

\begin{tabular}{|c|c|c|c|c|c|c|}
\hline & Species & Method & Resolution & Condition and state & References & PDB \\
\hline \multirow{14}{*}{ TRPML1 } & Mouse & Cryo-EM in & & & Zhang et al. 2017 & \\
\hline & & -nanodisc & $5.4 \AA$ & Closed state & & 5YE5 \\
\hline & & -amphipols & $5.8 \AA$ & State1 (closed) & & $5 Y E 2$ \\
\hline & & & $7.4 \AA$ & State2 (wide upper gate) & & $5 Y D Z$ \\
\hline & & & $7.7 \AA$ & State3 (wide lower gate) & & 5YE1 \\
\hline & Mouse & $\begin{array}{l}\text { Cryo-EM (lipid } \\
\text { nanodisc) }\end{array}$ & $3.59 \AA$ & Open state & Chen et al. 2017 & $5 \mathrm{WPV}$ \\
\hline & & & $3.64 \AA$ & Closed 1 & & $5 \mathrm{WPQ}$ \\
\hline & & & $3.75 \AA$ & Closed 2 & & $5 \mathrm{WPT}$ \\
\hline & Human & Cryo-EM & $3.72 \AA$ & Apo-structure (closed) & Schmiege et al. & $5 \mathrm{WJ} 5$ \\
\hline & & & & & 2017 & $5 \mathrm{WJ} 9$ \\
\hline & & & $3.49 \AA$ & Agonist bound (open) & & \\
\hline & Human & Cryo-EM & $3.6 \AA$ & $\mathrm{PI}(3,5) \mathrm{P}_{2}$-bound & Fine et al. 2018 & $6 \mathrm{E} 7 \mathrm{P}$ \\
\hline & & & & $\mathrm{PI}(4,5) \mathrm{P}_{2}$-bound & & $6 \mathrm{E} 7 \mathrm{Y}$ \\
\hline & & & & $\mathrm{PI}(3,5) \mathrm{P}_{2} / \mathrm{ML}-\mathrm{SA} 1$-bound & & $6 \mathrm{E} 7 \mathrm{Z}$ \\
\hline \multicolumn{7}{|l|}{ TRPML2 } \\
\hline \multirow[t]{4}{*}{ TRPML3 } & $\begin{array}{l}\text { Callithrix } \\
\text { jacchus }\end{array}$ & Cryo-EM & $2.9 \AA$ & Open state & Hirschi et al. 2017 & $5 \mathrm{~W} 3 \mathrm{~S}$ \\
\hline & Human & Cryo-EM & $4.06 \AA$ & Apo channel & Zhou et al. 2017 & 6AYE \\
\hline & & & $3.62 \AA$ & $\begin{array}{l}\text { TRPML3/ML-SA1 } \\
\text { complex }\end{array}$ & & $6 \mathrm{AYF}$ \\
\hline & & & $4.65 \AA$ & At $\mathrm{pH} 4.8$ & & $6 \mathrm{AYG}$ \\
\hline \multirow[t]{3}{*}{$\begin{array}{r}\text { TRPP1- } \\
\text { PKD2 }\end{array}$} & Human & $\begin{array}{l}\text { Cryo-EM (lipid } \\
\text { nanodisc) }\end{array}$ & $3.0 \AA$ & $\begin{array}{l}\text { Closed/nonconductive } \\
\text { state }\end{array}$ & Shen et al. 2016 & $5 \mathrm{~T} 4 \mathrm{D}$ \\
\hline & Human & Cryo-EM & $3.5 \AA$ & PKD2-F604P mutant & Zheng et al. 2018 & $6 \mathrm{D} 1 \mathrm{~W}$ \\
\hline & Human & Cryo-EM & $4.2 \AA$ & Both gates closed & $\begin{array}{l}\text { Grieben et al. } \\
2017\end{array}$ & $5 \mathrm{~K} 47$ \\
\hline \multirow[t]{3}{*}{$\begin{array}{l}\text { TRPP2- } \\
\text { PKD2- } \\
\text { L1 }\end{array}$} & Human & Cryo-EM & $4.3 \AA$ & $\begin{array}{l}\text { In complex with cations } \\
\text { and lipids (different } \\
\text { activation states) }\end{array}$ & Wilkes et al. 2017 & $\begin{array}{l}5 \mathrm{MKF} \\
5 \mathrm{MKE}\end{array}$ \\
\hline & Human & Cryo-EM & $3.3 \AA$ & & Hulse et al. 2018 & 6DU8 \\
\hline & Mouse & Cryo-EM & $3.38 \AA$ & Open state & Su et al. $2018 b$ & $5 \mathrm{Z} 1 \mathrm{~W}$ \\
\hline \multicolumn{7}{|c|}{$\begin{array}{l}\text { TRPP3- } \\
\text { PKD2- } \\
\text { L2 }\end{array}$} \\
\hline $\begin{array}{l}\text { PKD1 }+ \\
\text { TRPP1 }\end{array}$ & Human & Cryo-EM & $3.6 \AA$ & $\begin{array}{l}\text { PKD1/PKD2 complex } \\
\text { assembled in a 1:3 ratio }\end{array}$ & Su et al. 2018a & $6 \mathrm{~A} 70$ \\
\hline \multirow[t]{5}{*}{ TRPV1 } & Rat & Cryo-EM & $3.28 \AA$ & Apo state (closed) & Liao et al. 2013 & $\begin{array}{l}3 \mathrm{~J} 5 \mathrm{P} \\
(3 \mathrm{~J} 9 \mathrm{~J})\end{array}$ \\
\hline & Rat & Cryo-EM & $3.8 \AA$ & $\begin{array}{l}\text { Resiniferatoxin and } \\
\text { capsaicin (activated) }\end{array}$ & Cao et al. 2013 & 3J5Q \\
\hline & & & $4.2 \AA$ & $\begin{array}{l}\text { Capsazepin (fully open } \\
\text { state) }\end{array}$ & & $3 \mathrm{~J} 5 \mathrm{R}$ \\
\hline & Rat & $\begin{array}{l}\text { Cryo-EM (lipid } \\
\text { nanodisc) }\end{array}$ & $3.28 \AA$ & & Gao et al. 2016 & 5IRZ \\
\hline & & & $3.43 \AA$ & $\begin{array}{l}\text { In complex with } \\
\text { capsazepine }\end{array}$ & & 5IS0 \\
\hline
\end{tabular}


TRP Channels and Calcium Signaling

Table 2. Continued

\begin{tabular}{|c|c|c|c|c|c|c|}
\hline & Species & Method & Resolution & Condition and state & References & PDB \\
\hline & & & $2.95 \AA$ & $\begin{array}{l}\text { In complex with DkTx } \\
\text { and RTX }\end{array}$ & & 5IRX \\
\hline \multirow[t]{5}{*}{ TRPV2 } & Rabbit & Cryo-EM & $4 \AA$ & $\begin{array}{l}\text { Nonconductive } \\
\quad \text { (desensitized state) }\end{array}$ & $\begin{array}{l}\text { Zubcevic et al. } \\
2016\end{array}$ & $5 \mathrm{AN} 8$ \\
\hline & Rat & Cryo-EM & $\sim 5 \AA$ & $\begin{array}{l}\text { Apo state (constitutive } \\
\text { activity) }\end{array}$ & Huynh et al. 2016 & $5 \mathrm{HI} 9$ \\
\hline & Rabbit & Cryo-EM & $3.5 \AA$ & $\begin{array}{l}\text { Resiniferatoxin (RTx) } \\
\text { and/or } \mathrm{Ca}^{2+} \text {-bound } \\
\text { (open state) }\end{array}$ & $\begin{array}{l}\text { Zubcevic et al. } \\
2018 \text { b }\end{array}$ & $\begin{array}{l}\text { 6BWM } \\
6 \mathrm{BWJ}\end{array}$ \\
\hline & Rat & Cryo-EM & $3.6 \AA$ & In partially closed state & Dosey et al. 2018 & $6 \mathrm{BO} 5$ \\
\hline & & & $4 \AA$ & $\begin{array}{l}\text { Open state (resolved pore } \\
\text { turret domain) }\end{array}$ & & $6 \mathrm{BO} 4$ \\
\hline \multirow[t]{5}{*}{ TRPV3 } & Mouse & Cryo-EM & $4.3 \AA$ & Closed apo & Singh et al. 2018a & 6DVW \\
\hline & & & $4 \AA$ & $\begin{array}{l}\text { Agonist (2-APB)-bound } \\
\text { open states }(+ \text { mutant })\end{array}$ & & $\begin{array}{c}\text { 6DVY/ } \\
\mathrm{Z}\end{array}$ \\
\hline & Human & Cryo-EM & $3.4 \AA$ & Apo state & $\begin{array}{l}\text { Zubcevic et al. } \\
\text { 2018a }\end{array}$ & $6 \mathrm{MHO}$ \\
\hline & & & $3.2 \AA$ & Sensitized conformation & & $6 \mathrm{MHS}$ \\
\hline & & & $<3.5 \AA$ & In the presence of $2-\mathrm{APB}$ & & $\begin{array}{l}6 \mathrm{MHV} / \\
\mathrm{W} / \mathrm{X}\end{array}$ \\
\hline \multirow[t]{3}{*}{ TRPV4 } & $\begin{array}{c}\text { Xenopus } \\
\text { laevis }\end{array}$ & $\begin{array}{l}\text { Cryo-EM + } \\
\text { crystal } \\
\text { structure }\end{array}$ & $3.8 \AA$ & Apo state (closed state) & Deng et al. 2018 & $6 \mathrm{BBJ}$ \\
\hline & & & & In the presence of cesium & & $\begin{array}{l}6 \mathrm{C} 8 \mathrm{~F} \\
6 \mathrm{C} 8 \mathrm{G}\end{array}$ \\
\hline & & & & Barium, gadolinium & & $6 \mathrm{C} 8 \mathrm{H}$ \\
\hline \multirow[t]{4}{*}{ TRPV5 } & Rabbit & Cryo-EM & $3.5-4 \AA$ & $\begin{array}{l}\text { In complex with its } \\
\text { inhibitor econazole } \\
\text { (closed state) }\end{array}$ & $\begin{array}{l}\text { Hughes et al. } \\
\text { 2018a }\end{array}$ & $6 \mathrm{~B} 5 \mathrm{~V}$ \\
\hline & Rabbit & Cryo-EM & & Lipid-bound in detergent & $\begin{array}{l}\text { Hughes et al. } \\
2018 b\end{array}$ & 6DMR \\
\hline & & & & $\begin{array}{l}\mathrm{PI}(4,5) \mathrm{P}_{2} \text {-bound in } \\
\text { nanodisc }\end{array}$ & & 6DMU \\
\hline & & & & CaM-bound in detergent & & 6DMW \\
\hline \multirow[t]{9}{*}{ TRPV6 } & Rat & $\begin{array}{l}\text { Crystal } \\
\text { structure }\end{array}$ & $3.25 \AA$ & TRPV6 & $\begin{array}{l}\text { Saotome et al. } \\
2016\end{array}$ & 5IWK \\
\hline & & & & $\begin{array}{l}\text { In the presence of } \mathrm{Ca}^{2+} \\
\text { (open state) }\end{array}$ & & 5IWP \\
\hline & & & & Barium & & 5IWR \\
\hline & & & & Gadolinium & & 5IWT \\
\hline & Human & Cryo-EM & $3.6 \AA$ & In nanodiscs & $\begin{array}{l}\text { McGoldrick et al. } \\
2018\end{array}$ & $6 \mathrm{BO} 8$ \\
\hline & & & $4.0 \AA$ & In amphipols & & $6 \mathrm{BO} 9$ \\
\hline & & & & $\begin{array}{l}\text { TRPV6-R470E in } \\
\text { amphipols }\end{array}$ & & $6 \mathrm{BOA}$ \\
\hline & Rat & & & TRPV6 in nanodisc & & $6 \mathrm{BOB}$ \\
\hline & Rat & Crystal & $3.45 \AA$ & In complex with $2-\mathrm{AP}$ & Singh et al. $2018 \mathrm{c}$ & $6 \mathrm{DO} 7$ \\
\hline
\end{tabular}


L. Vangeel and T. Voets

Table 2. Continued

\begin{tabular}{|c|c|c|c|c|c|}
\hline Species & Method & Resolution & Condition and state & References & PDB \\
\hline & & & $\begin{array}{l}\text { In complex with 2-APB- } \\
\mathrm{Br}\end{array}$ & & $6 \mathrm{D} 7 \mathrm{~V}$ \\
\hline & & & $\mathrm{Y} 466 \mathrm{~A}$ & & $6 \mathrm{D} 7 \mathrm{P}$ \\
\hline & & & $\mathrm{Y} 466 \mathrm{~A}+$ in complex with & & 6D7Q/ \\
\hline & & & 2-APB & & $\mathrm{X}$ \\
\hline & & & Y467A & & $6 \mathrm{D} 7 \mathrm{~S}$ \\
\hline & & & $\begin{array}{l}\text { Y467A + in complex with } \\
2-\mathrm{APB}\end{array}$ & & $6 \mathrm{D} 7 \mathrm{~T}$ \\
\hline Human & Cryo-EM & $3.9 \AA$ & $\begin{array}{l}\text { TRPV6 in complex with } \\
\text { calmodulin }\end{array}$ & Singh et al. $2018 \mathrm{~b}$ & $6 \mathrm{E} 2 \mathrm{~F}$ \\
\hline Rat & & $3.6 \AA$ & $\begin{array}{l}\text { TRPV6 in complex with } \\
\text { calmodulin }\end{array}$ & & $6 \mathrm{E} 2 \mathrm{G}$ \\
\hline
\end{tabular}

PDB, Protein Data Bank; 2-APB, 2-aminoethoxydiphenyl borate; AICT, allyl isothiocyanate; CaM, calmodulin; PIP2, phosphatidylinositol bisphosphate; cryo-EM, cryo-electron microscopy; RTX, ultrapotent vanilloid resiniferatoxin; DkTx, double-knot toxin.

served atop each tetrameric channel complex. Each toxin binds at the extracellular loop of the outer pore region of one subunit and connects to the pore helix of a neighboring subunit (Cao et al. 2013).

By comparing the pore structures of TRPV1 in these three different conformational states, significant plasticity was noticed in the central pore, both at the level of the selectivity filter and at a lower region of the pore formed by S6. The funnel-like structure that comprises the pore starts with a rather wide outer pore, followed by a short selectivity filter. When the channel is in the unliganded state, the narrowest point of the filter, $4.6 \AA$, is created by two opposed carbonyl oxygens at position G643 (Liao et al. 2013). Further down the pore, the most constricted site is located at I679 (S6), where the distance between side chains measures $5.3 \AA$ in the unliganded state (Liao et al. 2013). Upon vanilloid binding, I679 rotates away from the central axis causing an expansion to $7.6 \AA$ (Cao et al. 2013). In addition, in the RTX/DkTx structure, the pore helix tilts away from the central axis, thereby increasing the distance between the G643 carbonyls to $7.6 \AA$ (Cao et al. 2013). Overall, these findings have led to the notion of a dual gating mechanism: in the unliganded conformation, both the upper and lower gate are constricted; the lower gate opens following vanilloid ligand binding; and binding of $\mathrm{DkTx}$, and possibly allosteric coupling with the lower gate, leads to additional opening of the upper gate.

\section{A Flurry of TRP Channel Structures}

Following the determination of TRPV1 structures using cryo-EM, similar approaches were successfully applied to many other members of the TRP channel superfamily. Moreover, by purifying TRP channels into lipid nanodiscs structural analysis of the channels in a more native, membrane-like environment has been achieved. Table 2 provides a summary of the published structures of TRP channels, with the cautionary note that this list is growing steadily.

At this point, structures of at least one member of every TRP channel subfamily are available, and representatives of each subfamily are represented in Figure 3. In general, these different TRP channels structures have a have several features, including a homotetrameric organization with fourfold symmetry, and a structurally conserved TM organization that resembles that of other members of the superfamily of voltage-gated cation channels. One particular exception is the recent structure of a heterotetramer formed between the polycystic kidney disease-related 
TRP Channels and Calcium Signaling

PKD1 and TRPP1-PKD2 (Su et al. 2018a). Whereas TRPP1-PKD2 has all the features of a 6-TM TRP subunit and can form a homotetrameric channel, PKD1 is a much larger protein with an exoplasmic amino terminus and $11 \mathrm{TM}$ helices. Of these 11 TM domains, the last six show homology to the TM segments of TRP channels, and one such subunit can apparently engage with three TRPP1-PKD2 subunits to form an asymmetric PKD1-PKD2 complex. However, the natural occurrence and functional properties of this complex remain to be established.

Despite common global architectures, there are several subfamily-specific features. In the exoplasmic region, TRPML and TRPP members exhibit a large structured domain formed by the S1-S2 linkers, known as the luminal domain (TRPML) and the polycystin domain (TRPP), which forms a fenestrated canopy-like structure atop the channel (Shen et al. 2016; Chen et al. 2017; Grieben et al. 2017; Hirschi et al. 2017; Schmiege et al. 2017). In contrast, members of the other subfamilies have only short and largely unstructured exoplasmic loops. In TRPA, TRPC, and TRPV channels, the amino terminus contains multiple ARDs, which are implicated in the protein-protein interaction, trafficking, and gating. The number of ARDs ranges from three ARDs in TRPCs to 24 repeats in TRPA1. TRPM channels have relatively long amino termini but lack ARDs, as do the short amino-terminal tails of TRPP and TRPML channels. In their proximal carboxyl terminus following the S6 helix, TRPC, TRPV, and TRPM channels contain a highly conserved TRP domain, implicated in channel gating, which is not found in TRPA, TRPP, and

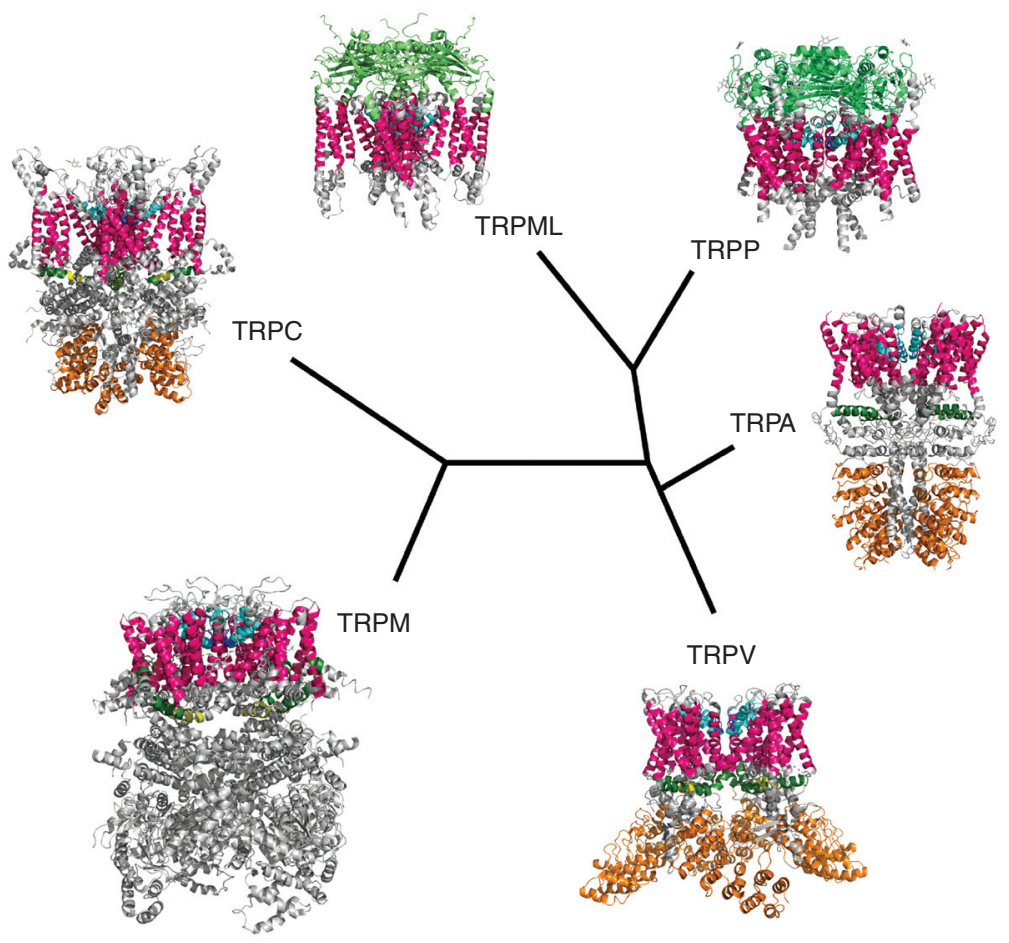

Figure 3. Cladogram of mammalian transient receptor potential (TRP) channel subfamilies and their structures. A representative structure of a member of each subfamily is illustrated: hTRML1 (PDB ID: 5WJ9), hTRPP2 (5K47), hTRPA1 (3J9P), rTRPV1 (3J5P), hTRPM4 (6BQR), and hTRPC3 (6CUD). Specific domains are indicated with the following color code: pink=transmembrane domains $(\mathrm{S} 1-\mathrm{S} 6)$, light blue= pore region, dark blue $=$ selectivity filter, orange $=$ ankyrin repeat domain, dark green $=$ TRP domain, yellow $=$ TRP box, and lime $=$ S1-S2 extracellular domain (luminal domain [TRPML] and polycystin domain [TRPP]). 
TRPML channels. At their distal carboxy terminal, three TRPM channels exhibit an integral enzyme domain: an atypical $\alpha$ kinase in TRPM6 and TRPM7, and a NUDIX domain in TRPM2. Below, we highlight the structural features that specifically relate to $\mathrm{Ca}^{2+}$ permeation and TRP channel regulation by $\mathrm{Ca}^{2+}$.

\section{STRUCTURAL INSIGHTS INTO $\mathrm{Ca}^{2+}$ PERMEATION}

The central ion-conducting pore of TRP channels can be divided into an upper part, which forms the narrow selectivity filter lined by residues from the S5-S6 linker, and a lower part lined by residues from $S 6$ that includes the lower gate. The lower gate is formed by hydrophobic residues that seal the lower part of the permeation pathway in the closed conformation, and rotate away to allow ion permeation upon channel activation (Cao et al. 2013; Gao et al. 2016). This movement may be dependent on a short $\pi$-helical segment observed in the middle of S6, which has been suggested to facilitate helix bending during gating (Hughes et al. 2018b; Singh et al. 2018a). In addition to the lower gate, structural evidence has been provided for the existence of a second, upper gate at the level of the selectivity filter in some but not all TRP channels (Deng et al. 2018). However, the exact relevance of this upper gate to TRP channel gating and ion permeation is currently unclear.

A key question is whether the different TRP channel structures provide a framework to explain the large diversity in $\mathrm{Ca}^{2+}$ permeability properties of TRP channel pores. To address this, we provide here a comparison between the pores of TRP channels that reflect the entire range of $\mathrm{Ca}^{2+}$ permeability observed within the TRP superfamily (Fig. 1): the highly $\mathrm{Ca}^{2+}$-selective TRPV6, the nonselective, $\mathrm{Ca}^{2+}$-permeable TRPV1, and the $\mathrm{Ca}^{2+}$-impermeable TRPM4 (Fig. 4).

\section{The $\mathrm{Ca}^{2+}$-Selective Pore of TRPV6}

TRPV6 and its close homolog TRPV5 are the only two highly calcium-selective TRP channels, with estimated $\mathrm{P}_{\mathrm{Ca}^{2+}} / \mathrm{P}_{\mathrm{Na}^{+}}$values $>100$ (Gunthorpe et al. 2002). Under normal ionic condi- tions, the inward current through TRPV6 is almost fully carried by $\mathrm{Ca}^{2+}$ ions (Nijenhuis et al. 2005). Earlier work combining structural modeling, the substituted cysteine accessibility method, and patch-clamp recordings, had already established that a short stretch of amino acids in the S5-S6 linker, TIIDG, forms the selectivity filter (Nilius et al. 2001), with the aspartate residue (D541) forming the narrowest part of the open pore, with an estimated diameter of $5.4 \AA$. In addition, it was shown that substituting D541 (and the corresponding D542 in TRPV5) by a noncharged residue abolishes calcium selectivity and blocks by other divalent cations (Voets et al. 2003). Many of these prestructural findings were corroborated by recent structures obtained using both X-ray crystallography and cryo-EM. Indeed, crystal structures of TRPV6 obtained in the absence and presence of $\mathrm{Ca}^{2+}$ confirm that the narrowest part of the pore is formed by the four side chains of D541, with a minimum interatomic distance of $4.6 \AA$, and that these aspartate side chains form a high-affinity site coordinating a single dehydrated $\mathrm{Ca}^{2+}$ ion (Saotome et al. 2016). Side-chain hydroxyls of T838 (also part of the TIIDG motif) participate in a second, lower-affinity binding site for a dehydrated $\mathrm{Ca}^{2+}$ ion 6-8 $\AA$ below the ring of aspartates, whereas a third binding site in the vestibule below the selectivity filter may accommodate ( partly) hydrated $\mathrm{Ca}^{2+}$. Note that, similar to other highly $\mathrm{Ca}^{2+}$-selective channels, TRPV6 permeates large currents carried by $\mathrm{Na}^{+}, \mathrm{K}^{+}$, and other monovalent cations in the absence of extracellular $\mathrm{Ca}^{2+}$ ions. In the wild-type channel, these monovalent currents are blocked by low micromolar concentrations of $\mathrm{Ca}^{2+}$ or $\mathrm{Cd}^{2+}$, and this inhibition is abolished when mutating D541 to a noncharged residue (Nilius et al. 2001).

Based on these results, a "knock-off" mechanism of $\mathrm{Ca}^{2+}$ permeation was proposed (Saotome et al.2016), where the binding of $\mathrm{Ca}^{2+}$ in an electronegative ring formed by D541 side chains is highly energetically favorable compared to the charge repulsion between the acidic side chains in the unbound state. This implicates that removal of $\mathrm{Ca}^{2+}$ from this site leads to immediate replacement by another $\mathrm{Ca}^{2+}$ ion, a process that 
A

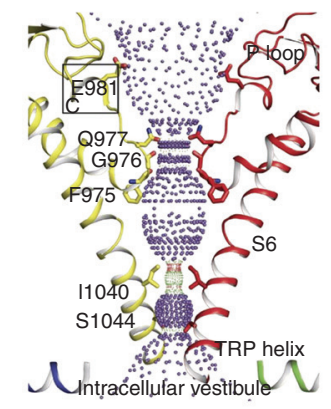

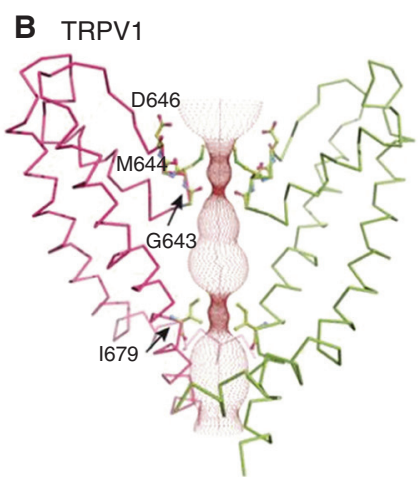

Figure 4. Structure of transient receptor potential (TRP) channel pores. Comparison of the pore domains of TRPM4 (left, $\mathrm{Ca}^{2+}$-impermeable), TRPV1 (middle, $\mathrm{Ca}^{2+}$-permeable, nonselective), and TRPV6 (right, $\mathrm{Ca}^{2+}$ selective). Structures are created from data in Winkler et al. (2017) (TRPM4), Liao et al. (2013) (TRPV1-apo state), and Hughes et al. (2018a) (TRPV6) (see text for more details).

may be facilitated by recruitment of $\mathrm{Ca}^{2+}$ ions from the external solution by the highly electronegative extracellular vestibule of TRPV6. In the absence of extracellular $\mathrm{Ca}^{2+}$ ions, the ring of aspartates is no longer occupied by tightly bound $\mathrm{Ca}^{2+}$ ions, thus allowing large fluxes of monovalent cations.

Interestingly, comparison of the structures of the closed and open TRPV6 pore did not reveal any significant conformational changes at the level of the selectivity filter. In contrast, there was significant widening of the lower part of the pore lined by S6 residues, apparently induced by an $\alpha$ - to $\pi$-helical transition in the middle of S6 (McGoldrick et al. 2018). Therefore, in the case of TRPV6, the selectivity filter is static and solely involved in ion selectivity, whereas channel opening is controlled by a single (lower) gate.

The $\mathrm{Ca}^{2+}$-Permeable Nonselective Pore of TRPV1

TRPV1, like the related TRPV2-TRPV4 and the majority of other TRP channels (Owsianik et al. 2006), encompasses a pore that is nonselective for cations and shows significant $\mathrm{Ca}^{2+}$ permeability. Several studies report $\mathrm{P}_{\mathrm{Ca}^{2}+} / \mathrm{P}_{\mathrm{Na}^{+}}$values for TRPV1 of approximately 10 (Caterina et al. 1997) and, under physiological ionic conditions, approximately $10 \%$ of the inward current is carried by $\mathrm{Ca}^{2+}$ ions. Very similar permeability properties have been described for TRPV2TRPV4.

The selectivity filter of these four $\mathrm{Ca}^{2+}$ permeable nonselective TRPV channels contains the motif TIGMGD/E (Deng et al. 2018). Mutating the aspartate in TRPV1 to a noncharged residue significantly reduces $\mathrm{P}_{\mathrm{Ca}^{2+}} / \mathrm{P}_{\mathrm{Na}^{+}}$, indicative of the essential role of negative charges in the selectivity filter for $\mathrm{Ca}^{2+}$ permeation (García-Martinez et al. 2000). However, in contrast to TRPV5 and TRPV6, the negatively charged side chain is not located at the narrowest part of the pore, which instead is lined by neutral methionine side chains and backbone carbonyls (Liao et al. 2013). As a result, TRPV1-TRPV4 lack a high-affinity $\mathrm{Ca}^{2+}$-binding site in the selectivity filter, thus explaining the poor discrimination between mono- and divalent cations. Note that in the unliganded state this narrowest constriction has a minimum diameter of $4.6 \AA$ (Liao et al. 2013), which increases to $7.6 \AA$ in the structure with RTX/DkTx (Cao et al. 2013). These dynamics at the level of the selectivity filter may contribute to the reported alterations in pore permeability properties upon strong stimulation of TRPV1, although further research is required to establish this. 
The $\mathrm{Ca}^{2+}$-Impermeable Pore of TRPM4

TRPM4 and the related TRPM5 are unique within the TRP superfamily in that they only conduct monovalent cations and are impermeable to $\mathrm{Ca}^{2+}$ (Liman 2007). Recent structures of TRPM4 reveal a normal ion-conducting pore with two constriction sites, similar to many other TRP channel structures. Although these structures do not clearly establish why TRPM4 fails to allow detectable permeation of $\mathrm{Ca}^{2+}$ ions, different mechanisms may contribute. First, the short but wide selectivity filter of TRPM4 consists of the motif FGQ, and thus does not contain any negatively charged amino acid, unlike other TRP channels (Winkler et al. 2017). Importantly, mutating the glutamine $\mathrm{Q}$ in the selectivity filter to a glutamate indeed resulted in detectable $\mathrm{Ca}^{2+}$ permeation through TRPM4 (Nilius et al. 2005), establishing the importance of negative charge. Nevertheless, TRPM2 and TRPM8 contain the same FGQ motif in their pore region, but are nonetheless able to permeate $\mathrm{Ca}^{2+}$. A different selectivity filter configuration, as their pore loop is one amino acid shorter compared to TRPM4 and TRPM5, might explain this conundrum. Second, residues in the lower gate may also play a role in the monovalent ion selectivity. Interestingly, a serine that is shown to interact with permeating $\mathrm{Na}^{+}$ions in the lower pore region is only conserved in TRPM4 and TRPM5, while other TRPM subfamily members contain an isoleucine at this position (Duan et al. 2018c). Note that TRPM4 contains a negative charge at the top of the ion permeation pathway, just outside the selectivity filter. This electronegative mouth may serve to attract cations, but the local negative charge is likely not strong enough to promote dehydration of divalent cations, which is necessary to permeate the pore (Duan et al. 2018c).

\section{STRUCTURAL INSIGHTS INTO $\mathrm{Ca}^{2+}$ REGULATION}

In addition to these insights into the ion permeation pathway, recent TRP channel structures also provide interesting novel structural clues toward understanding $\mathrm{Ca}^{2+}$-dependent processes that regulate channel gating (Figs. 2 and 5).
Intracellular $\mathrm{Ca}^{2+}$-Binding Site in TRP Channels

The activity of several members of the TRPM subfamily is enhanced by a direct binding of $\mathrm{Ca}^{2+}$ ions to the channel protein. In particular, the $\mathrm{Ca}^{2+}$-impermeable TRPM4 and TRPM5 are activated by a cytosolic $\mathrm{Ca}^{2+}$ rise in a voltage-dependent manner. Cryo-EM structures of TRPM4 were obtained in both $\mathrm{Ca}^{2+}$-bound and -unbound conformations, revealing a $\mathrm{Ca}^{2+}$-binding site located at, and coordinated by, side chains of TM domains S2 and S3 (Fig. 5; Autzen et al. 2018). Based on these structures, $\mathrm{Ca}^{2+}$ binding to TRPM4 triggers a cascade of small conformational effects throughout the whole channel, to prime the channel for voltage-dependent opening.

Interestingly, several of the residues implicated in $\mathrm{Ca}^{2+}$ binding in TRPM4 are conserved only in other members of the TRPM family that show $\mathrm{Ca}^{2+}$-dependent gating, namely, TRPM2, TRPM5, and TRPM8. Moreover a high-resolution structure of the ADPR-activated TRPM2 channel in the presence of $\mathrm{Ca}^{2+}$ (Huang et al. 2018; Wang et al. 2018) revealed, similar to TRPM4, a $\mathrm{Ca}^{2+}$-binding site at the cytosolic side of S2 and S3 of both the human and the zebrafish TRPM2 orthologs (Fliegert et al. 2018). Structural comparison with the apo structure indicates a repositioning of $\mathrm{S} 3$ upon $\mathrm{Ca}^{2+}$ binding, enabling movement of the S4-S5 linker to facilitate activation. At the functional level, earlier studies showed that mutation of residues in this region indeed impairs activation of TRPM2 in the presence of $\mathrm{Ca}^{2+}$ (Winking et al. 2012). Although structural data to confirm this are not yet available, is likely that this cytosolic $\mathrm{Ca}^{2+}$-binding site is also present in TRPM5 and TRPM8. In support of this notion, mutations of the corresponding amino acids in TRPM8 abolish the $\mathrm{Ca}^{2+}$-dependent activation by icilin, while leaving responses to cold and menthol intact (Chuang et al. 2004).

In addition to these TRPM channels, structural evidence has also been provided for intracellular $\mathrm{Ca}^{2+}$-binding sites in other TRP channels, including a well-defined EF hand in the proximal carboxyl terminus of TRPP1$\mathrm{PKD} 2$, implicated in $\mathrm{Ca}^{2+}$-dependent activation 


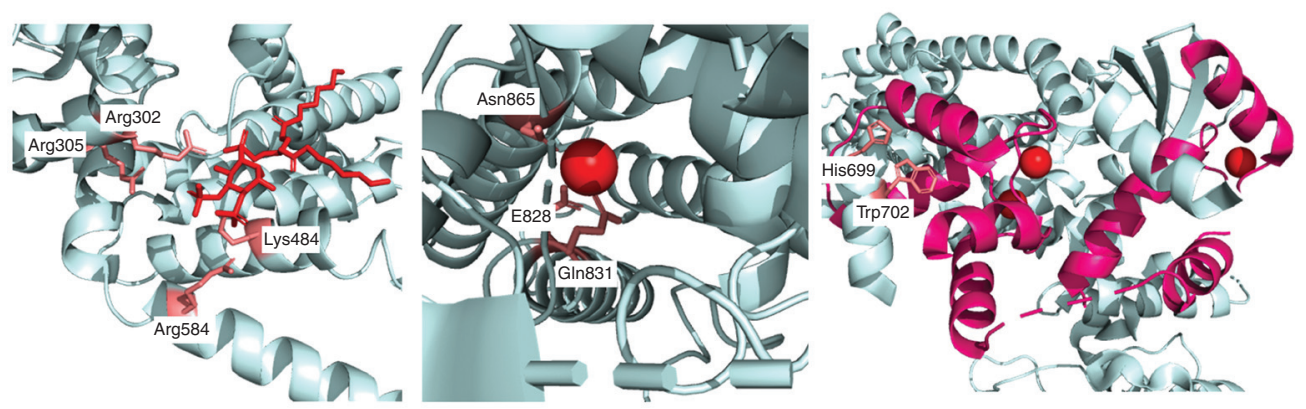

Figure 5. Structural elements underlying $\mathrm{Ca}^{2+}$-dependent regulation of transient receptor potential (TRP) channels. (Left) Interaction between phosphatidylinositol bisphosphate $\left(\mathrm{PIP}_{2}\right)$ and the $\mathrm{PIP}_{2}$-binding pocket in TRPV5, which is formed by residues from the amino terminus (Arg302, Arg305), the S4-S5 linker (Lys484), and the S6-helix (Arg584). $\mathrm{PIP}_{2}$ is shown in red, interacting amino acids in salmon. (Center) $\mathrm{A} \mathrm{Ca}^{2+}$ ion (red) interacting with TRPM4 via residues Glu828, Gln831 (from S2), and Asn865 and Asp868 (from S3). (Right) $\mathrm{Ca}^{2+}$ ions (red) bound to calmodulin (pink), interacting with the carboxyl terminus of TRPV 5 via an interaction with His699, Trp702, and Thr709 (salmon).

of the channel (Yang et al. 2016; Grieben et al. 2017; Wilkes et al. 2017).

\section{Cytosolic Interactions between TRPV Channels and $\mathrm{Ca}^{2+}-\mathrm{CaM}$}

CaM consists of two globular domains, connected by a flexible linker. Two $\mathrm{Ca}^{2+}$ ions can bind to the EF-hand motifs of every domain, resulting in a maximum of four $\mathrm{Ca}^{2+}$ ions bound to a single CaM. $\mathrm{Ca}^{2+}$ binding induces a conformational change in the backbone of $\mathrm{CaM}$, allowing interaction with a wide range of target proteins, including TRP channels. The number of TRP channels interacting with $\mathrm{CaM}$ is large (see trpchannel.org/proteins/show?id=calmodulin), and the effects it can trigger are equally diverse. Furthermore, there can be multiple CaM interaction sites within one TRP channel, where binding can mediate divergent effects on channel function (Zhu 2005).

The first high-resolution insights into CaMTRP channel interactions were provided by a crystal structure of $\mathrm{Ca}^{2+}$-bound $\mathrm{CaM}$ in complex with a 35-residue carboxy-terminal segment of TRPV1 (Lau et al. 2012). This study revealed that CaM clasps around the helical carboxyl terminus of TRPV1 in a $\mathrm{Ca}^{2+}$-dependent manner, and that disruption of the interaction slows $\mathrm{Ca}^{2+}$-dependent channel desensitization, although a second CaM interaction site in the amino terminus was found that plays a more prominent role in this process.

Recently, structures were determined for the full-length TRPV5 and TRPV6 in a complex with $\mathrm{Ca}^{2+}$-bound $\mathrm{CaM}$ (Hughes et al. 2018b; Singh et al. 2018b). In the structure of TRPV5 saturated with $\mathrm{Ca}^{2+}-\mathrm{CaM}$, both lobes of $\mathrm{CaM}$ interact with different sections of the carboxyl terminus via numerous hydrophobic contacts (Hughes et al. 2018b). This results in an occupation of the tryptophan amino acids in the lower gate of TRPV5, directly obstructing ion permeation (Fig. 5). The critical role of this interaction in $\mathrm{Ca}^{2+}$-CaM-mediated effects was established in functional studies showing that mutating the critical tryptophan residues abolishes $\mathrm{Ca}^{2+}$-CaM-dependent channel inhibition. This mechanism represents an important negative feedback loop that regulates calcium influx in $\mathrm{Ca}^{2+}$-reabsorbing epithelia. A very similar structural mechanism has been put forward for the close homolog TRPV6, as structures showed a comparable binding of $\mathrm{CaM}$ to the carboxyl terminus of TRPV6, with the C-lobe of CaM inserted into the pore's intracellular entrance (Singh et al. 2018b). Currently, there is insufficient structural information to establish whether this mechanism is conserved in other TRP channels. 


\section{TRP Channel Interactions with $\mathrm{PIP}_{2}$}

The level of $\mathrm{PIP}_{2}$, the most abundant phosphoinositide in the inner leaflet of the plasma membrane of mammalian cells, is typically around $1 \%$ of total plasma membrane anionic phospholipids (Czech 2000). Despite being a minor constituent of the plasma membrane, $\mathrm{PIP}_{2}$ has a major impact on the functioning of many, if not all TRP channels (Voets and Nilius 2007). Both a rise in intracellular $\mathrm{Ca}^{2+}$ levels, acting via $\mathrm{Ca}^{2+}$-dependent PLC (see above), as well as activation of PLC downstream of GPCRs and receptor tyrosine kinases, can result in a rapid decrease in $\mathrm{PIP}_{2}$ levels, constituting a common and powerful mechanism of TRP channel regulation (Rohacs 2014). Most TRP channels are inhibited when $\mathrm{PIP}_{2}$ levels decrease, although inhibitory effects of $\mathrm{PIP}_{2}$ have also been observed in some TRP channels (Qin 2007; Rohacs 2014). Recently, by combining cryo-EM with nanodisc technology, several structures have been obtained of TRP channels in a biological membrane-like environment, allowing structural characterization of $\mathrm{PIP}_{2}$ interaction sites.

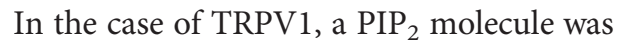
identified in the binding pocket for vanilloids such as capsaicin and RTX, suggesting that these activating ligands must displace $\mathrm{PIP}_{2}$ to bind and activate the channel. A cryo-EM structure of TRPV5 in the presence of $\mathrm{PIP}_{2}$ revealed a single $\mathrm{PIP}_{2}$ molecule interacting with the $\mathrm{N}$ linker, the S4-S5 linker, and the S6 helix of the channel (Hughes et al. 2018b), a finding that correlated with molecular dynamics predictions of a $\mathrm{PIP}_{2}$-binding site in the close homolog TRPV6 (Fig. 5). Comparing structures of TRPV5 with and without bound $\mathrm{PIP}_{2}$ revealed important conformational rearrangements in the channel (Hughes et al. 2018b). Upon binding of $\mathrm{PIP}_{2}$ the aspartate residues in the selectivity filter change orientation, clearing the initial road of the ion-conducting pathway. In addition, the lower gate of the pore extends wide enough to allow the flow of hydrated $\mathrm{Ca}^{2+}$ ions. These results form a beautiful example of how high-resolution structures can elucidate previously mysterious mechanisms of TRP channel regulation.

\section{CONCLUSION AND OUTLOOK}

TRP channel research benefited greatly from the recent resolution revolution. TRPV1 was the first full-length high-resolution membrane protein structure that was unraveled without the need for crystallizing the protein, representing a milestone for the fields of structural biology and TRP channel biology alike.

Thanks to the growing number of channel structures, including members of every TRP subfamily, subgroup, we are now able to visualize different conformational states leading to channel gating, rationalize ion permeation and define the details of TRP channel interactions with regulatory proteins, lipids, and ions. In this review, we have selectively highlighted novel insights related to $\mathrm{Ca}^{2+}$ permeation and $\mathrm{Ca}^{2+}$-dependent regulation of these channels. Undoubtedly, these novel insights and further structural work will not only fuel fundamental research into TRP channel function and regulation, but also increase our understanding of the etiology of TRP channel-related human diseases and assist in the rational design of pharmacological therapies for such diseases.

\section{ACKNOWLEDGMENTS}

This work was supported by grants from KU Leuven Research Council, the Queen Elisabeth Medical Foundation for Neurosciences, and the Belgian Foundation Against Cancer.

\section{REFERENCES}

Arias-Darraz L, Cabezas D, Colenso CK, Alegría-Arcos M, Bravo-Moraga F, Varas-Concha I, Almonacid DE, Madrid R, Brauchi S. 2015. A transient receptor potential ion channel in Chlamydomonas shares key features with sensory transduction-associated TRP channels in mammals. Plant Cell 27: 177-188. doi:10.1105/tpc.114.131862

Autzen HE, Myasnikov AG, Campbell MG, Asarnow D Julius D, Cheng Y. 2018. Structure of the human TRPM4 ion channel in a lipid nanodisc. Science 359: 228-232. doi:10.1126/science.aar4510

Barrera NP, Shaifta Y, McFadzean I, Ward JP, Henderson RM, Edwardson JM. 2007. AFM imaging reveals the tetrameric structure of the TRPC1 channel. Biochem Biophys Res Commun 358: 1086-1090. doi:10.1016/j.bbrc .2007.05.039 
Berridge MJ. 2017. Calcium signalling in health and disease Biochem Biophys Res Commun 485: 5. doi:10.1016/j.bbrc .2017.01.098

Bonnington JK, McNaughton PA. 2003. Signalling pathways involved in the sensitisation of mouse nociceptive neurones by nerve growth factor. J Physiol 551: 433-446. doi:10.1113/jphysiol.2003.039990

Cao E, Liao M, Cheng Y, Julius D. 2013. TRPV1 structures in distinct conformations reveal activation mechanisms. Nature 504: 113-118. doi:10.1038/nature12823

Caterina MJ, Schumacher MA, Tominaga M, Rosen TA, Levine JD, Julius D. 1997. The capsaicin receptor: A heat-activated ion channel in the pain pathway. Nature 389: 816-824. doi:10.1038/39807

Chen Q, She J, Zeng W, Guo J, Xu H, Bai XC, Jiang Y. 2017. Structure of mammalian endolysosomal TRPML1 channel in nanodiscs. Nature 550: 415-418. doi:10.1038/na ture24035

Cheng Y. 2015. Single-particle cryo-EM at crystallographic resolution. Cell 161: 450-457. doi:10.1016/j.cell.2015.03 .049

Chuang HH, Prescott ED, Kong H, Shields S, Jordt SE, Basbaum AI, Chao MV, Julius D. 2001. Bradykinin and nerve growth factor release the capsaicin receptor from PtdIns $(4,5) \mathrm{P}_{2}$-mediated inhibition. Nature 41 1: 957-962. doi:10 $.1038 / 35082088$

Chuang HH, Neuhausser WM, Julius D. 2004. The supercooling agent icilin reveals a mechanism of coincidence detection by a temperature-sensitive TRP channel. Neuron 43: 859-869. doi:10.1016/j.neuron.2004.08.038

Clapham DE. 2003. TRP channels as cellular sensors. Nature 426: 517-524. doi:10.1038/nature02196

Czech MP. 2000. PIP 2 and PIP $_{3}$ : Complex roles at the cell surface. Cell 100: 603-606. doi:10.1016/S0092-8674(00) 80696-0

Deng Z, Paknejad N, Maksaev G, Sala-Rabanal M, Nichols CG, Hite RK, Yuan P. 2018. Cryo-EM and X-ray structures of TRPV4 reveal insight into ion permeation and gating mechanisms. Nat Struct Mol Biol 25: 252-260. doi:10.1038/s41594-018-0037-5

Doerner JF, Gisselmann G, Hatt H, Wetzel CH. 2007. Transient receptor potential channel A1 is directly gated by calcium ions. J Biol Chem 282: 13180-13189. doi:10 .1074/jbc.M607849200

Dong XP, Cheng X, Mills E, Delling M, Wang F, Kurz T, Xu H. 2008. The type IV mucolipidosis-associated protein TRPML1 is an endolysosomal iron release channel. Nature 455: 992-996. doi:10.1038/nature07311

Dong XP, Shen D, Wang X, Dawson T, Li X, Zhang Q, Cheng X, Zhang Y, Weisman LS, Delling M, et al. 2010. PI $(3,5) \mathrm{P}_{2}$ controls membrane trafficking by direct activation of mucolipin $\mathrm{Ca}^{2+}$ release channels in the endolysosome. Nat Commun 1: 38. doi:10.1038/ncomms1037

Dosey TL, Wang Z, Fan G, Zhang Z, Serysheva II, Chiu W, Wensel TG. 2018. TRPV2 ion channel gating through allosteric domain coupling revealed by Cryo-EM. http:// dx.doi.org/10.2139/ssrn.3155836

Duan J, Li J, Zeng B, Chen GL, Peng X, Zhang Y, Wang J, Clapham DE, Li Z, Zhang J. 2018a. Structure of the mouse TRPC4 ion channel. Nat Commun 9: 3102. doi:10.1038/ s41467-018-05247-9
Duan J, Li Z, Li J, Hulse RE, Santa-Cruz A, Valinsky WC, Abiria SA, Krapivinsky G, Zhang J, Clapham DE. 2018b. Structure of the mammalian TRPM7, a magnesium channel required during embryonic development. Proc Natl Acad Sci 15: E8201-E8210. doi:10.1073/pnas .1810719115

Duan J, Li Z, Li J, Santa-Cruz A, Sanchez-Martinez S, Zhang J, Clapham DE. 2018c. Structure of full-length human TRPM4. Proc Natl Acad Sci 115: 2377-2382. doi:10 $.1073 /$ pnas. 1722038115

Fan C, Choi W, Sun W, Du J, Lu W. 2018. Structure of the human lipid-gated cation channel TRPC3. eLife 7: e36852. doi:10.7554/eLife.36852

Fine M, Schmiege P, Li X. 2018. Structural basis for PtdInsP2-mediated human TRPML1 regulation. Nat Commun 9: 4192. doi:10.1038/s41467-018-06493-7

Fliegert R, Bauche A, Wolf Perez AM, Watt JM, Rozewitz MD, Winzer R, Janus M, Gu F, Rosche A, Harneit A, et al. 2017. $2^{\prime}$-Deoxyadenosine $5^{\prime}$-diphosphoribose is an endogenous TRPM2 superagonist. Nat Chem Biol 13: 1036-1044. doi:10.1038/nchembio.2415

Fliegert R, Hölzer HT, Guse AH. 2018. TRPM2 activation: Paradigm shifted? Cell Calcium 76: 132-134. doi:10.1016/ j.ceca.2018.11.001

Gao Y, Cao E, Julius D, Cheng Y. 2016. TRPV1 structures in nanodiscs reveal mechanisms of ligand and lipid action. Nature 534: 347-351. doi:10.1038/nature17964

García-Martinez C, Morenilla-Palao C, Planells-Cases R, Merino JM, Ferrer-Montiel A. 2000. Identification of an aspartic residue in the P-loop of the vanilloid receptor that modulates pore properties. J Biol Chem 275: 32552-32558. doi:10.1074/jbc.M002391200

Gaudet R. 2008. TRP channels entering the structural era. $J$ Physiol 586: 3565-3575. doi:10.1113/jphysiol.2008 .155812

Gees M, Owsianik G, Nilius B, Voets T. 2012. TRP channels. Compr Physiol 2: 563-608. doi:10.1002/cphy.c110026

Grieben M, Pike AC, Shintre CA, Venturi E, El-Ajouz S, Tessitore A, Shrestha L, Mukhopadhyay S, Mahajan P, Chalk R, et al. 2017. Structure of the polycystic kidney disease TRP channel Polycystin-2 (PC2). Nat Struct Mol Biol 24: 114-122. doi:10.1038/nsmb.3343

Gunthorpe MJ, Benham CD, Randall A, Davis JB. 2002. The diversity in the vanilloid (TRPV) receptor family of ion channels. Trends Pharmacol Sci 23: 183-191. doi:10 .1016/S0165-6147(02)01999-5

Guo J, She J, Zeng W, Chen Q, Bai XC, Jiang Y. 2017. Structures of the calcium-activated, non-selective cation channel TRPM4. Nature 552: 205-209. doi:10.1038/na ture24997

Harteneck C, Plant TD, Schultz G. 2000. From worm to man: Three subfamilies of TRP channels. Trends Neurosci 23: 159-166. doi:10.1016/S0166-2236(99)01532-5

Hasan R, Zhang X. 2018. $\mathrm{Ca}^{2+}$ regulation of TRP ion channels. Int J Mol Sci 19: E1256. doi:10.3390/ijms19041256

Hirschi M, Herzik HM Jr, Wie J, Suo Y, Borschel WF, Ren D, Lander GC, Lee SY. 2017. Cryo-electron microscopy structure of the lysosomal calcium-permeable channel TRPML3. Nature 550: 411-414. doi:10.1038/na ture 24055 
Hoenderop JG, Voets T, Hoefs S, Weidema F, Prenen J, Nilius B, Bindels RJ. 2003. Homo- and heterotetrameric architecture of the epithelial $\mathrm{Ca}^{2+}$ channels TRPV5 and TRPV6. EMBO J 22: 776-785. doi:10.1093/emboj/cdg080

Hoenderop JG, Nilius B, Bindels RJ. 2005. Calcium absorption across epithelia. Physiol Rev 85: 373-422. doi:10 $.1152 /$ physrev.00003.2004

Holakovska B, Grycova L, Jirku M, Sulc M, Bumba L, Teisinger J. 2012. Calmodulin and S100A1 protein interact with $\mathrm{N}$ terminus of TRPM3 channel. J Biol Chem 287: 16645-16655. doi:10.1074/jbc.M112.350686

Huang Y, Winkler PA, Sun W, Lü W, Du J. 2018. Architecture of the TRPM2 channel and its activation mechanism by ADP-ribose and calcium. Nature 562: 145-149. doi:10 .1038/s41586-018-0558-4

Hughes TET, Lodowski DT, Huynh KW, Yazici A, Del Rosario J, Kapoor A, Basak S, Samanta A, Han X, Chakrapani S, et al. 2018a. Structural basis of TRPV5 channel inhibition by econazole revealed by cryo-EM. Nat Struct Mol Biol 25: 53-60. doi:10.1038/s41594-017-0009-1

Hughes TET, Pumroy RA, Yazici AT, Kasimova MA, Fluck EC, Huynh KW, Samanta A, Molugu SK, Zhou ZH, Carnevale V, et al. 2018b. Structural insights on TRPV5 gating by endogenous modulators. Nat Commun 9: 4198. doi:10.1038/s41467-018-06753-6

Hulse RE, Li Z, Huang RK, Zhang J, Clapham DE. 2018. Cryo-EM structure of the polycystin 2-11 ion channel. eLife 7: e36931. doi:10.7554/eLife.36931

Huynh KW, Cohen MR, Jiang J, Samanta A, Lodowski DT, Zhou ZH, Moiseenkova-Bell VY. 2016. Structure of the full-length TRPV2 channel by cryo-EM. Nat Commun 7: 11130. doi:10.1038/ncomms11130

Julius D. 2013. TRP channels and pain. Annu Rev Cell Dev Biol 29: 355-384. doi:10.1146/annurev-cellbio-101011155833

Kalia J, Swartz KJ. 2013. Exploring structure-function relationships between TRP and Kv channels. Sci Rep 3: 1523 doi:10.1038/srep01523

Kovalevskaya NV, Bokhovchuk FM, Vuister GW. 2012. The TRPV5/6 calcium channels contain multiple calmodulin binding sites with differential binding properties. J Struct Funct Genomics 13: 91-100. doi:10.1007/s10969-0129128-4

Kuang Q, Purhonen P, Hebert H. 2015. Structure of potassium channels. Cell Mol Life Sci 72: 3677-3693. doi:10 .1007/s00018-015-1948-5

Kühlbrandt W. 2014. Biochemistry. The resolution revolution. Science 343: 1443-1444. doi:10.1126/science .1251652

Lambers TT, Mahieu F, Oancea E, Hoofd L, de Lange F, Mensenkamp AR, Voets T, Nilius B, Clapham DE, Hoenderop JG, et al. 2006. Calbindin-D28K dynamically controls TRPV5-mediated $\mathrm{Ca}^{2+}$ transport. EMBO J 25: 29782988. doi:10.1038/sj.emboj.7601186

Lange I, Yamamoto S, Partida-Sanchez S, Mori Y, Fleig A, Penner R. 2009. TRPM2 functions as a lysosomal $\mathrm{Ca}^{2+}$ release channel in $\beta$ cells. Sci Signal 2: ra23. doi:10.1126/ scisignal.2000278

Lau SY, Procko E, Gaudet R. 2012. Distinct properties of $\mathrm{Ca}^{2+}$-calmodulin binding to $\mathrm{N}$ - and C-terminal regulato- ry regions of the TRPV1 channel. J Gen Physiol 140: 541555. doi:10.1085/jgp.201210810

Launay P, Fleig A, Perraud AL, Scharenberg AM, Penner R, Kinet JP. 2002. TRPM4 is a $\mathrm{Ca}^{2+}$-activated nonselective cation channel mediating cell membrane depolarization. Cell 109: 397-407. doi:10.1016/S0092-8674(02)00719-5

Liao M, Cao E, Julius D, Cheng Y. 2013. Structure of the TRPV1 ion channel determined by electron cryo-microscopy. Nature 504: 107-112. doi:10.1038/nature12822

Liman ER. 2007. The $\mathrm{Ca}^{2+}$-activated TRP channels: TRPM4 and TRPM5. In TRP ion channel function in sensory transduction and cellular signaling cascades (ed. WB Liedtke, S Heller). CRC, Boca Raton, FL.

Lukacs V, Thyagarajan B, Varnai P, Balla A, Balla T, Rohacs T. 2007. Dual regulation of TRPV1 by phosphoinositides. J Neurosci 27: 7070-7080. doi:10.1523/jneurosci.1866-07 .2007

Madej MG, Ziegler CM. 2018. Dawning of a new era in TRP channel structural biology by cryo-electron microscopy. Pflugers Arch 470: 213-225. doi:10.1007/s00424-0182107-2

Mathar I, Jacobs G, Kecskes M, Menigoz A, Philippaert K, Vennekens R. 2014. Trpm4. Handb Exp Pharmacol 222: 461-487. doi:10.1007/978-3-642-54215-2_18

McGoldrick LL, Singh AK, Saotome K, Yelshanskaya MV, Twomey EC, Grassucci RA, Sobolevsky AI. 2018. Opening of the human epithelial calcium channel TRPV6. $\mathrm{Na}$ ture 553: 233-237. doi:10.1038/nature25182

Medina DL, Di Paola S, Peluso I, Armani A, De Stefani D, Venditti R, Montefusco S, Scotto-Rosato A, Prezioso C, Forrester A, et al. 2015. Lysosomal calcium signalling regulates autophagy through calcineurin and TFEB. Nat Cell Biol 17: 288-299. doi:10.1038/ncb3114

Minke B, Wu C, Pak WL. 1975. Induction of photoreceptor voltage noise in the dark in Drosophila mutant. Nature 258: 84-87. doi:10.1038/258084a0

Moiseenkova-Bell VY, Wensel TG. 2009. Hot on the trail of TRP channel structure. J Gen Physiol 133: 239-244. doi:10.1085/jgp.200810123

Montell C, Rubin GM. 1989. Molecular characterization of the Drosophila trp locus: A putative integral membrane protein required for phototransduction. Neuron 2: 13131323. doi:10.1016/0896-6273(89)90069-X

Mulier M, Vriens J, Voets T. 2017. TRP channel pores and local calcium signals. Cell Calcium 66: 19-24. doi:10 .1016/j.ceca.2017.04.007

Nijenhuis T, Hoenderop JG, Bindels RJ. 2005. TRPV5 and TRPV6 in $\mathrm{Ca}^{2+}$ (re)absorption: Regulating $\mathrm{Ca}^{2+}$ entry at the gate. Pflugers Arch 451: 181-192. doi:10.1007/s00424005-1430-6

Nilius B, Voets T. 2013. The puzzle of TRPV4 channelopathies. EMBO Rep 14: 152-163. doi:10.1038/embor.2012 .219

Nilius B, Vennekens R, Prenen J, Hoenderop JG, Droogmans G, Bindels RJ. 2001. The single pore residue Asp542 determines $\mathrm{Ca}^{2+}$ permeation and $\mathrm{Mg}^{2+}$ block of the epithelial $\mathrm{Ca}^{2+}$ channel. J Biol Chem 276: 1020-1025. doi:10 $.1074 /$ jbc.M006184200

Nilius B, Prenen J, Janssens A, Owsianik G, Wang C, Zhu MX, Voets T. 2005. The selectivity filter of the cation 
channel TRPM4. J Biol Chem 280: 22899-22906. doi:10 .1074/jbc.M501686200

Nilius B, Owsianik G, Voets T, Peters JA. 2007. Transient receptor potential cation channels in disease. Physiol Rev 87: 165-217. doi:10.1152/physrev.00021.2006

Owsianik G, Talavera K, Voets T, Nilius B. 2006. Permeation and selectivity of TRP channels. Annu Rev Physiol 68: 685-717. doi:10.1146/annurev.physiol.68.040204.101406

Paulsen CE, Armache JP, Gao Y, Cheng Y, Julius D. 2015 Structure of the TRPA1 ion channel suggests regulatory mechanisms. Nature 525: 552. doi:10.1038/nature14871

Perraud AL, Fleig A, Dunn CA, Bagley LA, Launay P, Schmitz C, Stokes AJ, Zhu Q, Bessman MJ, Penner R, et al. 2001. ADP-ribose gating of the calcium-permeable LTRPC2 channel revealed by Nudix motif homology. $\mathrm{Na}$ ture 411: 595-599. doi:10.1038/35079100

Prawitt D, Monteilh-Zoller MK, Brixel L, Spangenberg C, Zabel B, Fleig A, Penner R. 2003. TRPM5 is a transient $\mathrm{Ca}^{2+}$-activated cation channel responding to rapid changes in $\left[\mathrm{Ca}^{2+}\right]_{\mathrm{i}}$. Proc Natl Acad Sci 100: 1516615171. doi:10.1073/pnas.2334624100

Qin F. 2007. Regulation of TRP ion channels by phosphatidylinositol-4,5-bisphosphate. Handb Exp Pharmacol 179: 509-525. doi:10.1007/978-3-540-34891-7_30

Rohacs T. 2014. Phosphoinositide regulation of TRP channels. Handb Exp Pharmacol 223: 1143-1176. doi:10 .1007/978-3-319-05161-1_18

Sano Y, Inamura K, Miyake A, Mochizuki S, Yokoi H, Matsushime H, Furuichi K. 2001. Immunocyte $\mathrm{Ca}^{2+}$ influx system mediated by LTRPC2. Science 293: 1327-1330. doi:10.1126/science.1062473

Saotome K, Singh AK, Yelshanskaya MV, Sobolevsky AI. 2016. Crystal structure of the epithelial calcium channel TRPV6. Nature 534: 506-511. doi:10.1038/nature17975

Schmiege P, Fine M, Blobel G, Li X. 2017. Human TRPML1 channel structures in open and closed conformations. Nature 550: 366-370. doi:10.1038/nature24036

Shen PS, Yang X, DeCaen PG, Liu X, Bulkley D, Clapham DE, Cao E. 2016. The structure of the polycystic kidney disease channel PKD2 in lipid nanodiscs. Cell 167: 763773.e11. doi:10.1016/j.cell.2016.09.048

Sierra-Valdez F, Azumaya CM, Romero LO, Nakagawa T, Cordero-Morales JF. 2018. Structure-function analyses of the ion channel TRPC3 reveal that its cytoplasmic domain allosterically modulates channel gating. J Biol Chem 293: 16102-16114. doi:10.1074/jbc.RA118.005066

Singh AK, McGoldrick LL, Sobolevsky AI. 2018a. Structure and gating mechanism of the transient receptor potential channel TRPV3. Nat Struct Mol Biol 25: 805-813. doi:10 1038/s41594-018-0108-7

Singh AK, McGoldrick LL, Twomey EC, Sobolevsky AI. 2018b. Mechanism of calmodulin inactivation of the calcium-selective TRP channel TRPV6. Sci Adv 4: eaau6088. doi:10.1126/sciadv.aau6088

Singh AK, Saotome K, McGoldrick LL, Sobolevsky AI. 2018c. Structural bases of TRP channel TRPV6 allosteric modulation by 2-APB. Nat Commun 9: 2465. doi:10 $.1038 / \mathrm{s} 41467-018-04828-y$

Su Q, Hu F, Ge X, Lei J, Yu S, Wang T, Zhou Q, Mei C, Shi Y. 2018a. Structure of the human PKD1/PKD2 complex. Science 361: eaat9819. doi:10.1126/science.aat9819
Su Q, Hu F, Liu Y, Ge X, Mei C, Yu S, Shen A, Zhou Q, Yan C, Lei J, et al. 2018b. Cryo-EM structure of the polycystic kidney disease-like channel PKD2L1. Nat Commun 9: 1192. doi:10.1038/s41467-018-03606-0

Tang Q, Guo W, Zheng L, Wu JX, Liu M, Zhou X, Zhang X, Chen L. 2018. Structure of the receptor-activated human TRPC6 and TRPC3 ion channels. Cell Res 28: 746-755. doi:10.1038/s41422-018-0038-2

Vandewauw I, De Clercq K, Mulier M, Held K, Pinto S, Van Ranst N, Segal A, Voet T, Vennekens R, Zimmermann $\mathrm{K}$, et al. 2018. A TRP channel trio mediates acute noxious heat sensing. Nature 555: 662-666. doi:10 $.1038 /$ nature26137

Venkatachalam K, Montell C. 2007. TRP channels. Annu Rev Biochem 76: 387-417. doi:10.1146/annurev .biochem.75.103004.142819

Vennekens R, Hoenderop JG, Prenen J, Stuiver M, Willems PH, Droogmans G, Nilius B, Bindels RJ. 2000. Permeation and gating properties of the novel epithelial $\mathrm{Ca}^{2+}$ channel. J Biol Chem 275: 3963-3969. doi:10.1074/jbc.275.6.3963

Vennekens R, Olausson J, Meissner M, Bloch W, Mathar I, Philipp SE, Schmitz F, Weissgerber P, Nilius B, Flockerzi $\mathrm{V}$, et al. 2007. Increased IgE-dependent mast cell activation and anaphylactic responses in mice lacking the calcium-activated nonselective cation channel TRPM4. Nat Immunol 8: 312-320. doi:10.1038/ni1441

Vinayagam D, Mager T, Apelbaum A, Bothe A, Merino F, Hofnagel O, Gatsogiannis C, Raunser S. 2018. Electron cryo-microscopy structure of the canonical TRPC4 ion channel. eLife 7: 36615. doi:10.7554/eLife.36615

Voets T, Nilius B. 2007. Modulation of TRPs by PIPs. $J$ Physiol 582: 939-944. doi:10.1113/jphysiol.2007.132522

Voets T, Janssens A, Prenen J, Droogmans G, Nilius B. 2003. $\mathrm{Mg}^{2+}$-dependent gating and strong inward rectification of the cation channel TRPV6. J Gen Physiol 121: 245-260. doi:10.1085/jgp.20028752

Voets T, Janssens A, Droogmans G, Nilius B. 2004. Outer pore architecture of a $\mathrm{Ca}^{2+}$-selective TRP channel. J Biol Chem 279: 15223-15230. doi:10.1074/jbc.M312076200

Wang L, Fu TM, Zhou Y, Xia S, Greka A, Wu H. 2018. Structures and gating mechanism of human TRPM2. Science 362: eaav4809. doi:10.1126/science.aav4809

Whited AM, Park PS. 2014. Atomic force microscopy: A multifaceted tool to study membrane proteins and their interactions with ligands. Biochim Biophys Acta 1838: 56-68. doi:10.1016/j.bbamem.2013.04.011

Wilkes M, Madej MG, Kreuter L, Rhinow D, Heinz V, De Sanctis S, Ruppel S, Richter RM, Joos F, Grieben M, et al. 2017. Molecular insights into lipid-assisted $\mathrm{Ca}^{2+}$ regulation of the TRP channel Polycystin-2. Nat Struct Mol Biol 24: 123-130. doi:10.1038/nsmb.3357

Winking M, Hoffmann DC, Kühn C, Hilgers RD, Luckhoff A, Kühn FJ. 2012. Importance of a conserved sequence motif in transmembrane segment S3 for the gating of human TRPM8 and TRPM2. PLOS ONE 7: e49877. doi:10.1371/journal.pone.0049877

Winkler PA, Huang Y, Sun W, Du J, Lu W. 2017. Electron cryo-microscopy structure of a human TRPM4 channel. Nature 552: 200-204. doi:10.1038/nature24674

Xiao R, Tang J, Wang C, Colton CK, Tian J, Zhu MX. 2008. Calcium plays a central role in the sensitization of TRPV 3 
L. Vangeel and T. Voets

channel to repetitive stimulations. J Biol Chem 283: 61626174. doi:10.1074/jbc.M706535200

Yamaguchi H, Matsushita M, Nairn AC, Kuriyan J. 2001. Crystal structure of the atypical protein kinase domain of a TRP channel with phosphotransferase activity. Mol Cell 7: 1047-1057. doi:10.1016/S1097-2765(01)00256-8

Yang Y, Hodsdon ME, Lolis EJ, Ehrlich BE. 2016. Conformational dynamics of $\mathrm{Ca}^{2+}$-dependent responses in the polycystin-2 C-terminal tail. Biochem J 473: 285-296. doi:10.1042/BJ20151031

Yin Y, Wu M, Zubcevic L, Borschel WF, Lander GC, Lee SY. 2018. Structure of the cold- and menthol-sensing ion channel TRPM8. Science 359: 237-241. doi:10.1126/sci ence.aan 4325

Yu FH, Catterall WA. 2004. The VGL-chanome: A protein superfamily specialized for electrical signaling and ionic homeostasis. Sci STKE 2004: re15. doi:10.1126/stke $.2532004 \mathrm{re} 15$

Yue L, Peng JB, Hediger MA, Clapham DE. 2001. CaT1 manifests the pore properties of the calcium-release-activated calcium channel. Nature 410: 705-709. doi:10 $.1038 / 35070596$

Zhang X, Li X, Xu H. 2012. Phosphoinositide isoforms determine compartment-specific ion channel activity. Proc Natl Acad Sci 109: 11384-11389. doi:10.1073/pnas .1202194109

Zhang X, Cheng X, Yu L, Yang J, Calvo R, Patnaik S, Hu X, Gao Q, Yang M, Lawas M, et al. 2016. MCOLN1 is a ROS sensor in lysosomes that regulates autophagy. Nat Commun 7: 12109. doi:10.1038/ncomms12109

Zhang S, Li N, Zeng W, Gao N, Yang M. 2017. Cryo-EM structures of the mammalian endo-lysosomal TRPML1 channel elucidate the combined regulation mechanism. Protein Cell 8: 834-847. doi:10.1007/s13238-017-0476-5
Zhang X, Hu M, Yang Y, Xu H. 2018a. Organellar TRP channels. Nat Struct Mol Biol 25: 1009-1018. doi:10 .1038/s41594-018-0148-Z

Zhang Z, Tóth B, Szollosi A, Chen J, Csanády L. 2018b. Structure of a TRPM2 channel in complex with $\mathrm{Ca}^{2+}$ explains unique gating regulation. eLife 7: e36409. doi:10.7554/eLife.36409

Zheng W, Yang X, Hu R, Cai R, Hofmann L, Wang Z, Hu Q, Liu X, Bulkey D, Yu Y, et al. 2018. Hydrophobic pore gates regulate ion permeation in polycystic kidney disease 2 and 2L1 channels. Nat Commun 9: 2302. doi:10.1038/s41467018-04586-x

Zhou X, Li M, Su D, Jia Q, Li H, Li X, Yang J. 2017. Cryo-EM structures of the human endolysosomal TRPML3 channel in three distinct states. Nat Struct Mol Biol 24: 11461154. doi:10.1038/nsmb.3502

Zhu MX. 2005. Multiple roles of calmodulin and other $\mathrm{Ca}^{2+}$-binding proteins in the functional regulation of TRP channels. Pflugers Arch 451: 105-115. doi:10.1007/ s00424-005-1427-1

Zubcevic L, Herzik MA Jr, Chung BC, Liu Z, Lander GC, Lee SY. 2016. Cryo-electron microscopy structure of the TRPV2 ion channel. Nat Struct Mol Biol 23: 180-186. doi: $10.1038 /$ nsmb.3159

Zubcevic L, Herzik MA Jr, Wu M, Borschel WF, Hirschi M, Song AS, Lander GC, Lee SY. 2018a. Conformational ensemble of the human TRPV3 ion channel. Nat Commun 9: 4773. doi:10.1038/s41467-018-07117-w

Zubcevic L, Le S, Yang H, Lee SY. 2018b. Conformational plasticity in the selectivity filter of the TRPV2 ion channel. Nat Struct Mol Biol 25: 405-415. doi:10.1038/s41594018-0059-Z

Zurborg S, Yurgionas B, Jira JA, Caspani O, Heppenstall PA. 2007. Direct activation of the ion channel TRPA1 by $\mathrm{Ca}^{2+}$. Nat Neurosci 10: 277-279. doi:10.1038/nn1843 


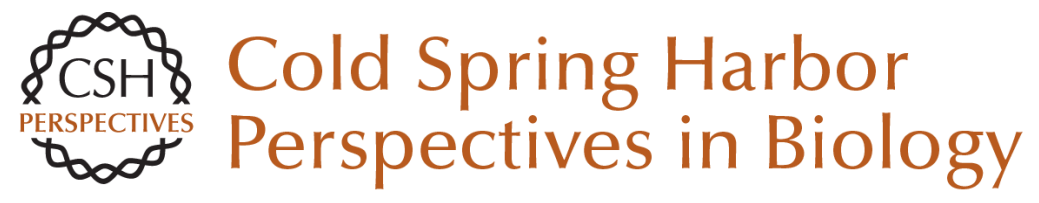

\title{
Transient Receptor Potential Channels and Calcium Signaling
}

\author{
Laura Vangeel and Thomas Voets
}

Cold Spring Harb Perspect Biol 2019; doi: 10.1101/cshperspect.a035048 originally published online March 25, 2019

\section{Subject Collection Calcium Signaling}

The Endoplasmic Reticulum-Plasma Membrane Junction: A Hub for Agonist Regulation of $\mathrm{Ca}^{2+}$ Entry

Hwei Ling Ong and Indu Suresh Ambudkar

Calcium-Handling Defects and Neurodegenerative Disease

Sean Schrank, Nikki Barrington and Grace E. Stutzmann

Lysosomal $\mathrm{Ca}^{2+}$ Homeostasis and Signaling in Health and Disease

Emyr Lloyd-Evans and Helen Waller-Evans

\section{$\mathrm{Ca}^{2+}$ Signaling in Exocrine Cells}

Malini Ahuja, Woo Young Chung, Wei-Yin Lin, et al.

Functional Consequences of Calcium-Dependent Synapse-to-Nucleus Communication: Focus on Transcription-Dependent Metabolic Plasticity Anna M. Hagenston, Hilmar Bading and Carlos Bas-Orth

Identifying New Substrates and Functions for an Old Enzyme: Calcineurin Jagoree Roy and Martha S. Cyert

Fundamentals of Cellular Calcium Signaling: A Primer

Martin D. Bootman and Geert Bultynck
Primary Active $\mathrm{Ca}^{2+}$ Transport Systems in Health and Disease Jialin Chen, Aljona Sitsel, Veronick Benoy, et al.

Signaling through $\mathrm{Ca}^{2+}$ Microdomains from Store-Operated CRAC Channels Pradeep Barak and Anant B. Parekh

Structural Insights into the Regulation of $\mathrm{Ca}^{2+}$ /Calmodulin-Dependent Protein Kinase II (CaMKII) Moitrayee Bhattacharyya, Deepti Karandur and John Kuriyan

Store-Operated Calcium Channels: From Function to Structure and Back Again Richard S. Lewis

Bcl-2-Protein Family as Modulators of $\mathrm{IP}_{3}$

Receptors and Other Organellar $\mathrm{Ca} 2+$ Channels Hristina Ivanova, Tim Vervliet, Giovanni Monaco, et al.

Calcium Signaling in Cardiomyocyte Function Guillaume Gilbert, Kateryna Demydenko, Eef Dries, et al.

Cytosolic $\mathrm{Ca}^{2+}$ Buffers Are Inherently $\mathrm{Ca}^{2+}$ Signal Modulators Beat Schwaller

For additional articles in this collection, see http://cshperspectives.cshlp.org/cgi/collection/

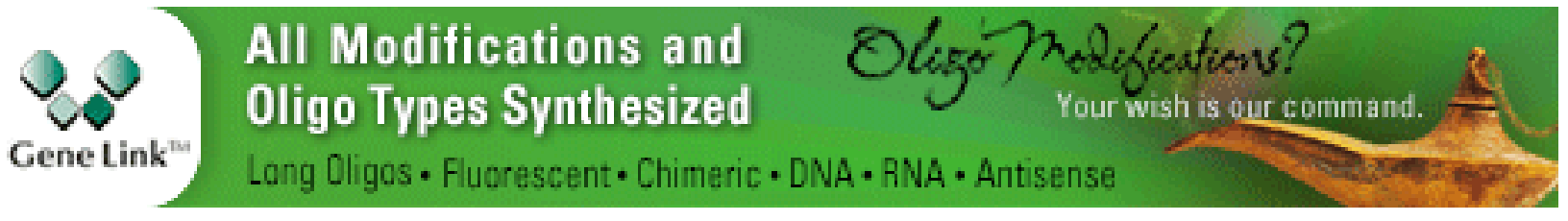


Role of Two-Pore Channels in Embryonic Development and Cellular Differentiation Sarah E. Webb, Jeffrey J. Kelu and Andrew L. Miller

\section{Organellar Calcium Handling in the Cellular \\ Reticular Network}

Wen-An Wang, Luis B. Agellon and Marek Michalak

For additional articles in this collection, see http://cshperspectives.cshlp.org/cgi/collection/

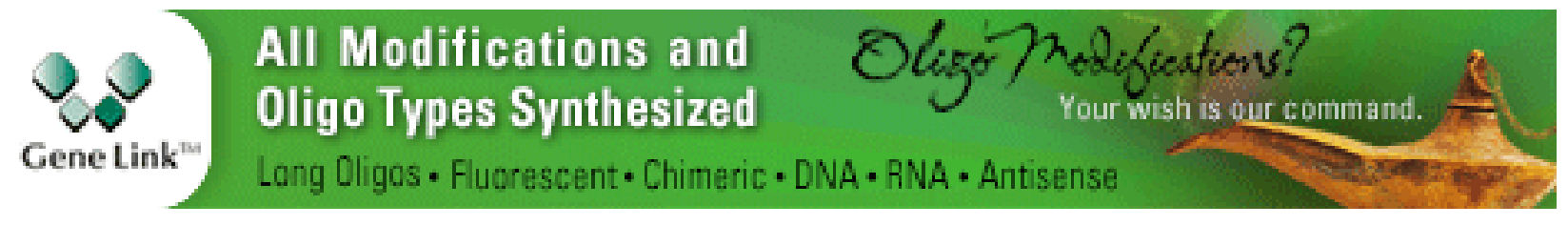

Copyright @ 2019 Cold Spring Harbor Laboratory Press; all rights reserved 